\title{
Activated Carbons Obtained from Orange Peels, Coffee Grounds, and Sunflower Husks-Comparison of Physicochemical Properties and Activity in the Alpha-Pinene Isomerization Process
}

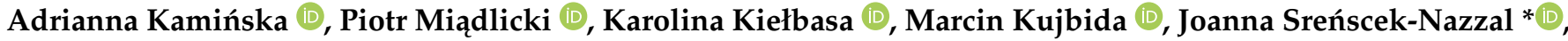 \\ Rafał Jan Wróbel and Agnieszka Wróblewska *(i)
}

Department of Catalytic and Sorbent Materials Engineering, Faculty of Chemical Technology and Engineering, West Pomeranian University of Technology in Szczecin, Piastów Ave. 42, 71-065 Szczecin, Poland; kaminska.adrianna@zut.edu.pl (A.K.); piotr.miadlicki@zut.edu.pl (P.M.); Karolina.Kielbasa@zut.edu.pl (K.K.); marcin.kujbida@zut.edu.pl (M.K.); rafal.wrobel@zut.edu.pl (R.J.W.)

* Correspondence: jsrenscek@zut.edu.pl (J.S.-N.); Agnieszka.Wroblewska@zut.edu.pl (A.W.)

Citation: Kamińska, A.; Miądlicki, P.; Kiełbasa, K.; Kujbida, M.;

Sreńscek-Nazzal, J.; Wróbel, R.J.; Wróblewska, A. Activated Carbons Obtained from Orange Peels, Coffee Grounds, and Sunflower Husks-Comparison of Physicochemical Properties and Activity in the Alpha-Pinene Isomerization Process. Materials 2021, 14, 7448. https://doi.org/10.3390/ ma14237448

Academic Editor: Antonio Di Bartolomeo

Received: 8 November 2021 Accepted: 2 December 2021 Published: 4 December 2021

Publisher's Note: MDPI stays neutral with regard to jurisdictional claims in published maps and institutional affiliations.

Copyright: (c) 2021 by the authors. Licensee MDPI, Basel, Switzerland. This article is an open access article distributed under the terms and conditions of the Creative Commons Attribution (CC BY) license (https:// creativecommons.org/licenses/by/ $4.0 /)$.

\begin{abstract}
This work presents studies on the preparation of porous carbon materials from waste biomass in the form of orange peels, coffee grounds, and sunflower seed husks. The preparation of activated carbons from these three waste materials involved activation with $\mathrm{KOH}$ followed by carbonization at $800{ }^{\circ} \mathrm{C}$ in an $\mathrm{N}_{2}$ atmosphere. This way of obtaining the activated carbons is very simple and requires the application of only two reactants. Thus, this method is cheap, and it does not generate much chemical waste. The obtained activated carbons were characterized by XRD, SEM, XPS, and XRF methods. Moreover, the textural properties, acidity, and catalytic activity of these materials were descried. During catalytic tests carried out in the alpha-pinene isomerization process (the use of the activated carbons thus obtained in the process of alpha-pinene isomerization has not been described so far), the most active were activated carbons obtained from coffee grounds and orange peels. Generally, the catalytic activity of the obtained materials depended on the pore size, and the most active activated carbons had more pores with sizes of 0.7-1.0 and 1.1-1.4 nm. Moreover, the presence of potassium and chlorine ions in the pores may also be of key importance for the alpha-pinene isomerization process. On the other hand, the acidity of the surface of the tested active carbons did not affect their catalytic activity. The most favorable conditions for carrying out the alpha-pinene isomerization process were the same for the three tested activated carbons: temperature $160{ }^{\circ} \mathrm{C}$, amount of the catalyst $5 \mathrm{wt} . \%$, and reaction time $3 \mathrm{~h}$. Kinetic studies were also carried out for the three tested catalysts. These studies showed that the isomerization over activated carbons from orange peels, coffee grounds, and sunflower seed husks is a first-order reaction.
\end{abstract}

Keywords: isomerization; alpha-pinene; biomass; activated carbon; camphene; limonene

\section{Introduction}

The synthesis of activated carbons from biomass has become an interesting way to obtain useful carbonaceous materials from raw materials that are a waste byproduct of the food industry. In recent years, carbon materials have become functional materials used on a large scale in many processes [1]. The problem with biowaste, which is constantly increasing, is the cost of the utilization of these materials [2]. The use of waste biomass, whose disposal is difficult and costly, can have a positive impact on the environment. The advantages of activated carbons obtained from biomass include efficiency and low production costs compared to commercial activated carbons [3]. Currently, materials of natural origin are often used as precursors in the synthesis of carbonaceous materials [4]. For this purpose are used, e.g., corn cobs [5], nutshells [6], pomegranate peels [7], coconut shells [8], coir pith [9], brazilian nutshell [10], palm fruits shells [11], oil palm fruits 
shells [12], olive stones [13], jackfruit shell waste and jackfruit peels [14], rice husk [15], banana peels [16], apple pulp [17], cotton stalk [18], and egg white biomass [19]. There are also reports describing biological precursors used in the production of carbonaceous materials [20].

One of the waste products used as precursors for the synthesis of activated carbons are orange peels. The citrus processing industry generates huge amounts of orange peels annually, which are the byproduct of the industrial extraction of citrus juices and waste from the production of jams and marmalades [21]. Orange juice is currently one of the most frequently chosen drinks by consumers around the world [22]. When oranges are processed into other food products, solid residues (peel, flesh, and seeds) and liquid waste, so-called "yellow water", are formed [23]. All of these wastes are composed of cellulose, hemicellulose, proteins, essential oils, pectins, sugars, organic acids, and salt [24]. During the treatment of this biowaste, it is necessary to neutralize the $\mathrm{pH}$ of the biomass, which is a serious problem for industries dealing with disposal [25]. This biomass contains large amounts of organic matter; therefore, it can pollute the environment if it is improperly stored and disposed of in an improper way [26].

Activated carbons produced from waste orange peels are used as adsorbents to remove organic compounds from the natural environment, e.g., naphthalene and 1-naphthol [27], dyes and chlorophenoxyacetic acid herbicide [28], for obtaining cathodes for the production of capacitors [29,30], and as catalysts (doped with $\mathrm{TiO}_{2}$ ) for $\mathrm{NO}_{\mathbf{X}}$ decomposition [31]. Moreover, carbonaceous materials obtained from orange peels are used as catalysts in the esterification of oleic acid and citric acid [32] and, after modification with iron ions, as $\mathrm{SO}_{2}$ sorbents [33]. A method for the preparation of selective and sensitive electrochemical sensors, which are used for the detection of toxic metal ions, was also described. In this method, palladium nanoparticles were deposited on the porous activated carbon obtained from orange peels [34].

Coffee is the second most consumed drink after water. Worldwide, about 500 billion cups are consumed annually, which equates to about nine million tons of waste from coffee grounds [35]. Coffee ground waste consists of caffeine, cellulose, hemicellulose, polysaccharides, and lignin, which, if not properly stored and disposed, can cause environmental pollution [36]. One of the ways to use coffee ground waste can be its application as a material for the production of activated carbons.

Activated carbons from coffee grounds are used as organic dye adsorbents [37], organic compounds adsorbents [38], and $\mathrm{CO}_{2}$ adsorbents [39]. Carbonaceous materials from coffee grounds are also used as the catalysts in many organic reactions, e.g., glycerol etherification [40], sulfamethoxazole degradation [41], and oleic acid and methanol esterification [42]. These materials also found applications in electrochemistry as anodes for lithium-ion batteries [43], as electrocatalysts [44], and as materials for energy storage [45].

In recent years, the importance of sunflower as an oil plant has increased. For years, both the production and the consumption of oils have steadily increased. The total annual world production of sunflower is about 20.9 million tons of seeds from about 18 million hectares of arable land [3]. Taking into account that sunflower husks constitute 21-30\% of the total weight of seeds and are the waste byproduct, appropriate methods should be developed that allow for environmentally friendly applications of this waste material [46]. The sunflower husk waste contains a significant amount of organic matter (proteins, cellulose, hemicelluloses, and lignin) that requires proper disposal and storage [47]. There are some reports in the scientific literature of sunflower husks used in the production of carbonaceous materials.

Carbonaceous materials obtained from waste sunflower found applications in the adsorption of Acid Violet 17 (AV17) [48], dyes (methylene blue and acid blue) [49], copper ions from wastewater [50], and phenol from aqueous solutions [51].

According to the current trends in science, the aim is to obtain high-value-added products from relatively cheap substrates, including alpha-pinene. Alpha-pinene is a cyclic organic and monoterpene compound [52]. This compound is obtained by a distillation 
of turpentine obtained from pine trees and is also a cheap raw material for many organic reactions [53]. Alpha-pinene is a commercially significant organic compound as it is the raw material for the synthesis of high-value-added products that are used in many industrial sectors (perfumery, cosmetics, food, and pharmaceuticals) [54,55].

The alpha-pinene isomerization reaction allows obtaining very important organic compounds, such as camphene and limonene. Both of these compounds are mainly used in cosmetics [56] and perfumery [57]. In addition, camphene is used as the raw material in obtaining insecticides [58] and as a pyrogen to produce nano/macroporous polycaprolactone [59]. However, the most common application of this compound is the production of synthetic camphor [57].

Limonene is an organic compound present in orange oil, which is produced from orange peels, a waste biomass from the orange juice industry [60,61]. Limonene is used as the raw material for obtaining many intermediates in laboratory organic chemistry and in the chemical industry, as well as a solvent for reactions performed with organic compounds, because it is not only cheap, but also biodegradable and not very toxic [62]. Limonene is also used as an aroma in food and drinks, as well as a fragrance in air fresheners. In the cosmetics industry, limonene is used as an ingredient in many cosmetics, including creams [63].

Finding the appropriate catalyst with high catalytic activity and selectivity to the alpha-pinene isomerization process is still difficult. In large-scale production, alphapinene is produced using titanium dioxide as the catalyst. The main disadvantages of this method are long reaction time, high process temperature, and low selectivity to bicyclic compounds [64].

Currently, the isomerization of alpha-pinene in the presence of catalysts is the subject of many laboratory-scale studies. The catalysts which are mainly used in the isomerization of alpha-pinene are acid-modified materials (HCl-modified clinoptilolite [65], $\mathrm{H}_{2} \mathrm{SO}_{4}$-modified clinoptilolite [66], acid-modified illite [67]), materials modified with metal ions [68] (Fe-loaded clinoptilolite [69], Al-MCM-41 [70], Ti-MCM-41 [71], Ti-SBA-15 [72], Al-SBA-15 [73], and GaSBA-15 [74]), calcined natural zeolites [75,76] natural zeolite [77], $\mathrm{W}_{2} \mathrm{O}_{3}-\mathrm{Al}_{2} \mathrm{O}_{3}$ catalysts [78], phosphotungstic heteropoly acids [79], acidic functionalized ionic liquids [80], mesoporous molecular sieves [81] and sulfated zirconia catalysts [82]. Table 1 compares the activity of the selected catalysts used in the process of alpha-pinene isomerization.

Table 1. Isomerization of alpha-pinene: conversion and selectivity using selected catalysts.

\begin{tabular}{|c|c|c|c|c|}
\hline Catalyst & $\begin{array}{c}\text { Conversion of } \\
\text { Alpha-Pinene } \\
\text { (mol.\%) }\end{array}$ & $\begin{array}{c}\text { Selectivity of } \\
\text { Camphene } \\
\text { (mol.\%) }\end{array}$ & $\begin{array}{c}\text { Selectivity of } \\
\text { Limonene (mol.\%) }\end{array}$ & Ref. \\
\hline HCl-modified clinoptilolite & 41 & 57 & 32 & [65] \\
\hline $\mathrm{SO}_{4} / \mathrm{Al}_{\mathrm{x}} \mathrm{ZrO}_{2}$ & 32 & & & [82] \\
\hline $\mathrm{W}_{2} \mathrm{O}_{3}-\mathrm{Al}_{2} \mathrm{O}_{3}$ & 73 & 55 & - & [78] \\
\hline Fe-loaded clinoptilolite & 100 & 38 & 2 & [69] \\
\hline Cr-loaded clinoptilolite & 100 & 24 & 11 & [69] \\
\hline $\mathrm{H}_{2} \mathrm{SO}_{4}$-modified clinoptilolite from Turkey & 18 & 46 & 19 & [66] \\
\hline Calcined natural zeolites & 100 & 32 & 25 & [75] \\
\hline Al-MCM-41 & 98 & 30 & 30 & [70] \\
\hline Ti-MCM-41 & 98 & 35 & 21 & [71] \\
\hline Ti-SBA-15 & 98 & 24 & 24 & [72] \\
\hline Activated carbon from coffee grounds & 84 & 34 & 38 & In this study \\
\hline
\end{tabular}

Considering the amount of biowaste produced in the form of orange peels, sunflower husks, and coffee grounds, as well as the problem of their storage and environmentally safe disposal, we should strive to develop very effective and environmentally friendly biowaste management technologies. The method of synthesis of activated carbons, presented in this work by our team, allows application of the biomass in the form of orange peels, coffee grounds, or sunflower husks as materials (after carbonization) for conducting catalytic reactions (isomerization reaction). In this way, we can obtain valuable products from relatively inexpensive raw materials. According to current knowledge, catalysts based on 
biomass (orange peels, sunflower husks, and coffee grounds) have not been used so far in the alpha-pinene isomerization reaction.

The carbonization method presented by our team is a simple way to obtain activated carbons from waste biomass from the food industry. In comparison to the methods presented in the literature $[28,30,34,39,45,51]$ the method of production of active carbons described in our work is very simple and it requires the application of only two chemical reactants, which makes it a very cheap method that generates little waste. The aim of this work was to obtain porous carbon materials from orange peels, coffee grounds, and sunflower seed husks and check their catalytic activity in the process of alpha-pinene isomerization. The production of activated carbons from waste materials involved chemical activation with $\mathrm{KOH}$ followed by carbonization at $800{ }^{\circ} \mathrm{C}$ in the atmosphere of $\mathrm{N}_{2}$. The aim of this stage was not only to obtain carbon materials, but also to characterize them using the following instrumental methods: XRD, SEM, XPS, and XRF. The textural properties of the tested materials were also described. Moreover, their acidity was determined. In the second stage, the catalytic activity of the obtained activated carbons was tested in the alpha-pinene isomerization process. The aim of this stage was to determine the best conditions for the isomerization process on the three tested catalysts. The aim of the last stage was to investigate the kinetics of the alpha-pinene isomerization process on catalyst samples tested in this work.

\section{Materials and Methods}

\subsection{Preparation of Raw Materials of Natural Origin for the Process of Chemical Activation and Carbonization}

In the studies, the following biomass materials were used to produce activated carbons: waste orange peels, coffee grounds, and sunflower husks.

The residual pulp was removed from the fresh orange peels. Coffee grounds and sunflower husks were washed several times with distilled water, and then each biomass was dried at ambient temperature for $24 \mathrm{~h}$. After $24 \mathrm{~h}$, the pre-dried biomass in the form of orange peels and sunflower husks was dried at $50{ }^{\circ} \mathrm{C}$ for another $24 \mathrm{~h}$. On the other hand, the coffee grounds were dried at $70^{\circ} \mathrm{C}$, because drying at the lower temperature caused the rotting of this raw material and was ineffective. After the completing of drying, the raw materials were ground into a powder in a laboratory grinder.

\subsection{Chemical Activation and Carbonization of Biomass}

Chemical activation of biomass was carried out with the use of a saturated aqueous solution of potassium hydroxide. Biomass was weighed into a plastic cup, and then a $\mathrm{KOH}$ solution was added in such an amount that the weight ratio of biomass to activator was 1:1. The material was then vigorously mixed until the raw material was clearly saturated with $\mathrm{KOH}$ solution and left at ambient temperature for $3 \mathrm{~h}$. After this time, the impregnated material was placed in a laboratory dryer (Alpina, Konin, Poland) ( $19 \mathrm{~h}$, $\left.200{ }^{\circ} \mathrm{C}\right)$. Next the carbonaceous substrate impregnated in this way was carbonized. The process of thermal decomposition of biomass was carried out in a tube furnace (Czylok, Jastrzębie-Zdrój, Poland) in an inert gas atmosphere $\left(\mathrm{N}_{2}\right)$. The sample of biomass was heated to $800{ }^{\circ} \mathrm{C}$ for $1 \mathrm{~h}$; then, the samples were kept at a given temperature for $1 \mathrm{~h}$. After the carbonization process was completed, the sample was cooled to room temperature in a nitrogen atmosphere. The chemical activation and carbonization process were carried out in the same conditions and at the same stages for all waste materials.

The resulting carbon materials were named as follows:

O_AC - activated carbon from waste orange peels.

C_AC - activated carbon from coffee grounds.

S_AC-activated carbon from sunflower husks. 


\subsection{Characterization the Obtained Activated Carbons}

The ASAP Sorption Surface Area and Pore Size Analyzer (ASAP 2460, Micrometrics, Norcross, GA, USA, 2018) was used for textural characterization of carbon samples. Nitrogen adsorption isotherms were measured at $-196{ }^{\circ} \mathrm{C}$. In order to measure the absorption, the samples were degassed at $250{ }^{\circ} \mathrm{C}$ for $19 \mathrm{~h}$. The Brunauer-Emmett-Teller (BET) method was applied for calculation of the specific surface area. To estimate the value of the total pore volume $\left(\mathrm{V}_{\text {tot }}\right)$, the adsorbed gas (nitrogen) volume was determined at a relative pressure of $\sim 1$. Micropore volumes were calculated by DFT (density functional theory) based on the $\mathrm{N}_{2}$ adsorption (slit $\mathrm{N}_{2}$-DFT Model adsorption). Through application of the DFT model in the ASAP 2460 version 3.01 software package based on nitrogen sorption isotherms, the pore size distribution in the tested materials was determined.

Scanning electron microscopy with cold field emission (SU8020 Ultrahigh-Resolution Field-Emission Scanning Electron Microscope; Hitachi Ltd., Hitachi City, Japan, 2012) was used to observe the morphology of the obtained carbon samples. The samples were prepared as follows: the material was ground and then placed on a double-sided conductive carbon tape, which was stuck to the SEM stub.

The X-ray diffraction (XRD) patterns of the catalysts were recorded by an X-ray diffractometer (X'Pert-PRO, Panalytical Almelo, The Netherlands, 2012) using Cu $\mathrm{K}_{\alpha}(\lambda=0.154 \mathrm{~nm})$ as the radiation source in the $2 \theta$ range of $10-80^{\circ}$ with a step size of 0.026 .

The X-ray photoelectron spectroscopy measurements were performed in a commercial multipurpose (XPS, AES, LEED, UPS) ultrahigh vacuum (UHV) surface analysis system (PREVAC). The base pressure attainable in the system is low $\left(10^{-10} \mathrm{mbar}\right.$ range). The UHV system consists of preparation and analysis chambers. The analysis chamber was equipped with a kinetic electron energy analyzer (SES-2002, Scienta Scientific AB, Uppsala, Sweden, 2002) and nonmonochromatic X-ray photoelectron spectroscope (XPS, PREVAC, Rogów, Poland, 2007). The calibration of the spectrometer was performed using Ag $3 d_{5 / 2}$ transition. Samples in the form of powder were degassed under a vacuum for 1 day prior to measurements. The vacuum during XPS measurements was in the low range $\left(10^{-9} \mathrm{mbar}\right)$. The X-ray photoelectron spectroscopy was performed using $\mathrm{Mg}$ Ka radiation $(\mathrm{hn}=1253.7 \mathrm{eV}$ ).

The titration method was used to determine the concentration of acid centers in the activated carbons obtained from biomass [66]. The method of the determination of acid centers consisted of the following steps: $20 \mathrm{mg}$ of carbonaceous material was added to $10 \mathrm{~cm}^{3}$ of an aqueous solution of $\mathrm{NaOH}(0.01 \mathrm{M})$. Next, the mixture was placed in laboratory shaker at ambient temperature for $4 \mathrm{~h}$. Then, the material was centrifuged. In the next stage, the supernatant solution of the activated carbon sediment was taken, and its $\mathrm{pH}$ was determined. The $\mathrm{pH}$ was established by titration with a $0.01 \mathrm{M}$ aqueous solution of $\mathrm{HCl}$. Phenolphthalein was used as an indicator. In order to calculate the concentrations of the acid centers $(\mathrm{Ns})$ in the samples, the following formula was used:

$$
N s=\frac{\left(\left[\mathrm{OH}^{-}\right]_{0}-\left[\mathrm{OH}^{-}\right]_{4 h}\right) \times V}{m},
$$

where $\left[\mathrm{OH}^{-}\right]$is the molar concentration of hydroxide groups determined by the titration method $\left(\mathrm{mol} / \mathrm{dm}^{3}\right), V$ is the volume of water solution of $\mathrm{NaOH}$ added to carbonaceous sample, and $m$ is the mass of activated carbon sample.

In this work, in order to deepen the analysis of the results of catalytic tests, the XRF (X-ray fluorescence) method was also applied. The studies were carried out with the use of the Epsilon3 apparatus (Panalytical, Almelo, The Netherlands, 2011).

\subsection{Alpha-Pinene Isomerization Method}

The reaction of alpha-pinene isomerization was carried out in a glass reactor in which a reflux condenser was installed. The glass reactor was placed in an oil bath. During studies of the isomerization, $3 \mathrm{~g}$ of alpha-pinene ( $98 \%$, Aldrich, St. Louis, MO, USA) and the appropriate amounts of activated carbons were used. The activity of carbonaceous materials was tested under the following conditions: reaction temperature $160^{\circ} \mathrm{C}$, catalyst 
amount $5 \mathrm{wt} . \%$, reaction time $3 \mathrm{~h}$, and speed of mixing $400 \mathrm{rpm}$. All activated carbons were next used to determine the most favorable reaction conditions. The influence of the following parameters was studied: temperature in the range of $140-180^{\circ} \mathrm{C}$, activated carbon content in the range of $1-5 \mathrm{wt} . \%$, and reaction time from $10 \mathrm{~min}$ to $330 \mathrm{~min}$.

The quantitative analyses of the post-reaction mixtures were performed by the gas chromatography method using a Thermo Electron FOCUS chromatograph with an FID detector and a ZB-1701 column (30 m $\times 0.53 \mathrm{~mm} \times 1 \mu \mathrm{m}, 14 \%$ cyanopropylphenyl, $86 \%$ dimethylpolysiloxane) (Anchem, Warszawa, Poland, 2009). The parameters of the chromatograph were as follows: helium flow $1.2 \mathrm{~mL} / \mathrm{min}$, injector temperature $220^{\circ} \mathrm{C}$, detector temperature $250{ }^{\circ} \mathrm{C}$, furnace temperature held isothermally for 2 min at $50^{\circ} \mathrm{C}$, increased at a rate of $6{ }^{\circ} \mathrm{C} / \mathrm{min}$ to $120^{\circ} \mathrm{C}$, then increased at a rate of $15^{\circ} \mathrm{C} / \mathrm{min}$ to $240^{\circ} \mathrm{C}$. The method of internal normalization was used for the quantitative analyses of the post-reaction mixtures.

\section{Results and Discussion}

\subsection{Characterization of the Obtained Materials}

In order to determine the textural properties $\left(\mathrm{S}_{\mathrm{BET}}, \mathrm{V}_{\text {tot }}, \mathrm{V}_{\text {mic }}\right)$ of the obtained materials, they were subjected to $\mathrm{N}_{2}$ sorption tests at $-196^{\circ} \mathrm{C}$. Table 2 shows the parameters characterizing the porous structure and acid-site concentrations for activated carbons obtained from biomass.

Table 2. Surface properties of tested activated carbons.

\begin{tabular}{ccccccc}
\hline Sample & $\begin{array}{c}\mathrm{S}_{\text {BET }} \\
\left(\mathbf{m}^{2} / \mathbf{g}\right)\end{array}$ & $\begin{array}{c}\mathbf{V}_{\text {tot }} \\
\left(\mathbf{c m}^{3} / \mathbf{g}\right)\end{array}$ & $\begin{array}{c}\mathbf{V}_{\text {mic }} \\
\left(\mathbf{c m}^{\mathbf{3}} / \mathbf{g}\right)\end{array}$ & $\begin{array}{c}\mathbf{V}_{\mathbf{0 . 7 3} \mathbf{1} \mathbf{~ n m}} \\
\left(\mathbf{c m}^{\mathbf{3}} / \mathbf{g}\right)\end{array}$ & $\begin{array}{c}\mathbf{V}_{\mathbf{1 - 2} \mathbf{~ n m}} \\
\left(\mathbf{c m}^{\mathbf{3}} / \mathbf{g}\right)\end{array}$ & $\begin{array}{c}\text { Acid-Site } \\
\text { Concentration } \\
(\mathbf{m m o l} / \mathbf{g})\end{array}$ \\
\hline O_AC & 1416 & 0.643 & 0.482 & 0.097 & 0.154 & 0.25 \\
C_AC & 1566 & 0.694 & 0.540 & 0.123 & 0.139 & 0.50 \\
S_AC & 1366 & 0.584 & 0.477 & 0.097 & 0.111 & 0.45 \\
\hline
\end{tabular}

The C_AC sample was characterized by the highest value of the specific surface area $\left(1566 \mathrm{~m}^{2} / \mathrm{g}\right)$. This material also had the largest total pore volume of $0.694 \mathrm{~cm}^{3} / \mathrm{g}$ and a micropore volume of $0.540 \mathrm{~cm}^{3} / \mathrm{g}$. For this sample, the volume of pores with a diameter of $0.73-1.0 \mathrm{~nm}$ was $0.123 \mathrm{~cm}^{3} / \mathrm{g}$, and it was the highest among all tested samples. The volume of pores with a diameter of $1-2 \mathrm{~nm}$ was $0.139 \mathrm{~cm}^{3} / \mathrm{g}$, and it was also the highest recorded value among the tested carbonaceous materials.

The S_AC sample showed the least developed surface among all obtained porous carbonaceous materials $\left(\mathrm{S}_{\mathrm{BET}}=1366 \mathrm{~m}^{2} / \mathrm{g}, \mathrm{V}_{\text {tot }}=0.584 \mathrm{~cm}^{3} / \mathrm{g}, \mathrm{V}_{\text {mic }}=0.477 \mathrm{~cm}^{3} / \mathrm{g}\right)$. The volume of pores with a diameter of $0.73-1.0 \mathrm{~nm}$ was $0.097 \mathrm{~cm}^{3} / \mathrm{g}$, and the volume of pores with a diameter of $1-2 \mathrm{~nm}$ was $0.154 \mathrm{~cm}^{3} / \mathrm{g}$.

The value of the specific surface area for the O_AC sample was $1416 \mathrm{~m}^{2} / \mathrm{g}$, the total pore volume was $0.643 \mathrm{~cm}^{3} / \mathrm{g}$, and the micropore volume was $0.482 \mathrm{~cm}^{3} / \mathrm{g}$. The volume of pores with a diameter of $0.73-1.0 \mathrm{~nm}$ was $0.097 \mathrm{~cm}^{3} / \mathrm{g}$, and the volume of pores with a diameter of $1-2 \mathrm{~nm}$ was $0.111 \mathrm{~cm}^{3} / \mathrm{g}$. These results show the highly developed specific surface area and porosity of the biomass-based materials. Similar results for this type of precursor were obtained by Wang et al. [39] from coffee grounds $\left(\mathrm{S}_{\mathrm{BET}}=1525 \mathrm{~m}^{2} / \mathrm{g}, \mathrm{V}_{\text {tot }}=0.77 \mathrm{~cm}^{3} / \mathrm{g}, \mathrm{V}_{\text {micro }}=0.54 \mathrm{~cm}^{3} / \mathrm{g}\right)$, Fernandez et al. [28] from orange peels $\left(\mathrm{S}_{\mathrm{BET}}=1090 \mathrm{~m}^{2} / \mathrm{g}, \mathrm{V}_{\text {tot }}=1.2 \mathrm{~cm}^{3} / \mathrm{g}, \mathrm{V}_{\text {micro }}=0.2364 \mathrm{~cm}^{3} / \mathrm{g}\right)$, and Zou et al. [83] from sunflower seed hulls $\left(\mathrm{S}_{\mathrm{BET}}=1908-2122 \mathrm{~m}^{2} / \mathrm{g}, \mathrm{V}_{\text {tot }}=1.023-1.627 \mathrm{~cm}^{3} / \mathrm{g}, \mathrm{V}_{\text {micro }}=\right.$ $\left.0.2-0.742 \mathrm{~cm}^{3} / \mathrm{g}\right)$.

Acid-site concentration was determined using the acid-base titration method. The highest concentration of acid centers was recorded for the activated carbon from coffee grounds $(0.50 \mathrm{mmol} / \mathrm{g})$. Similar values were recorded for the activated carbon from sunflower husk $(0.45 \mathrm{mmol} / \mathrm{g})$. The carbonaceous material from orange peels was characterized by the lowest content of acid sites $(0.25 \mathrm{mmol} / \mathrm{g})$.

Figure 1 shows the sorption isotherms of $\mathrm{N}_{2}$ at $-196^{\circ} \mathrm{C}$ for tested activated carbons. 


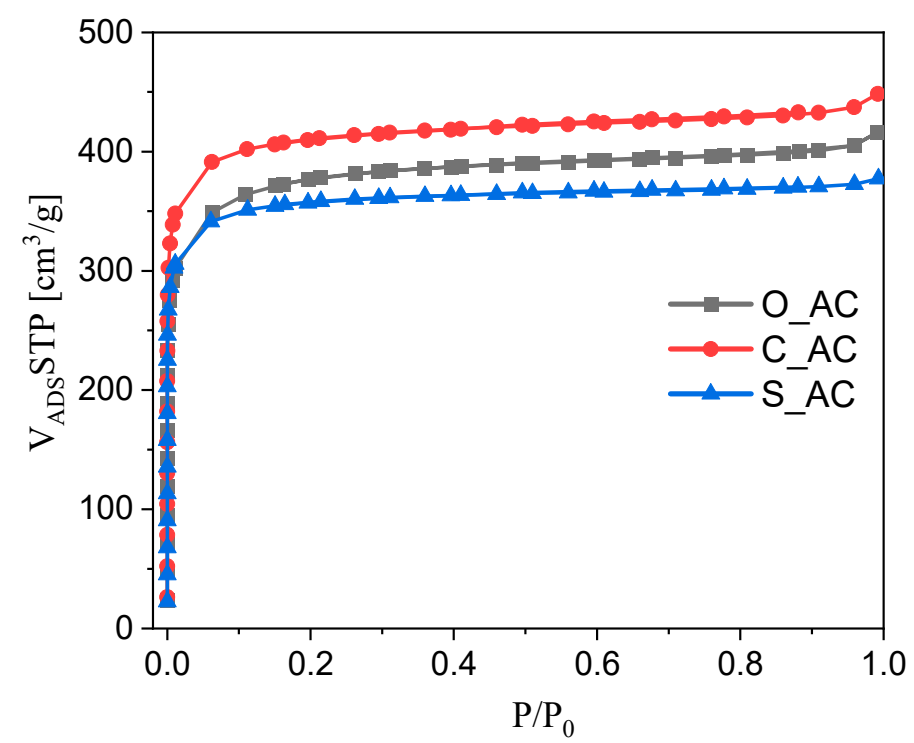

Figure 1. The sorption isotherms of $\mathrm{N}_{2}$ at $-196{ }^{\circ} \mathrm{C}$ for tested activated carbons.

It can be seen from Figure 1 that all samples showed a rapid increase in the gas adsorption in the initial relative pressure range and the adsorption isotherm determined parallel to the $\mathrm{P} / \mathrm{P}_{0}$ axis. This dependence proves that all activated carbons obtained from biomass are microporous materials [84]. All presented isotherms were reversible isotherms, for which no hysteresis loops were observed. The isotherms shown in Figure 1 correspond to class I isotherms as defined by the International Union of Pure and Applied Chemistry (IUPAC). Type I isotherms are characteristic for microporous materials [85]. Zhang et al. [86] and Yang et al. [87] also received similar I type isotherms which were characteristic for microporous materials.

An analysis of the pore size distribution of activated carbons was also performed. Curves were established via the analysis of adsorption isotherms $\mathrm{N}_{2}$ at $-196^{\circ} \mathrm{C}$. The pore distribution shown in Figure 2 confirms that the measured activated carbons, in addition to the micropores with a diameter of approximately $0.3 \mathrm{~nm}$ to $2 \mathrm{~nm}$, had narrow mesopores $(\sim 2.1-2.7 \mathrm{~nm})$ in their structure. Similar results were obtained by Serafin [88], Wei et al. [30], and Muniandy [89], where a high volume of micropores below $2 \mathrm{~nm}$ was also noted.

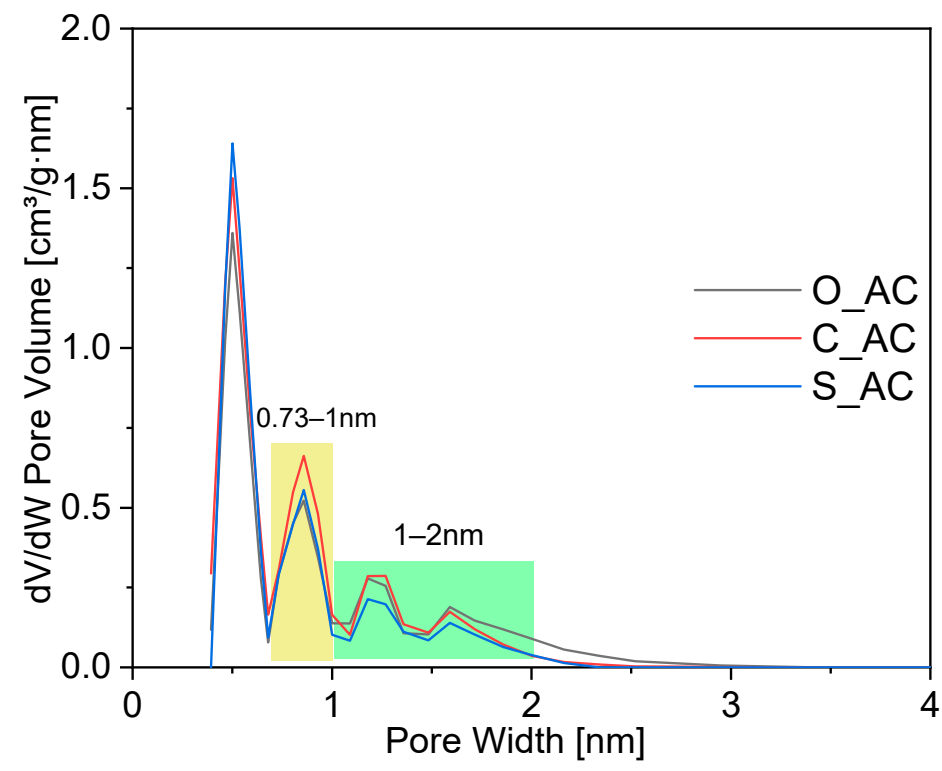

Figure 2. The pore volume distribution for tested activated carbons. 
Figure 3 illustrates the $X$-ray diffraction profiles of the O_AC, C_AC and S_AC samples.

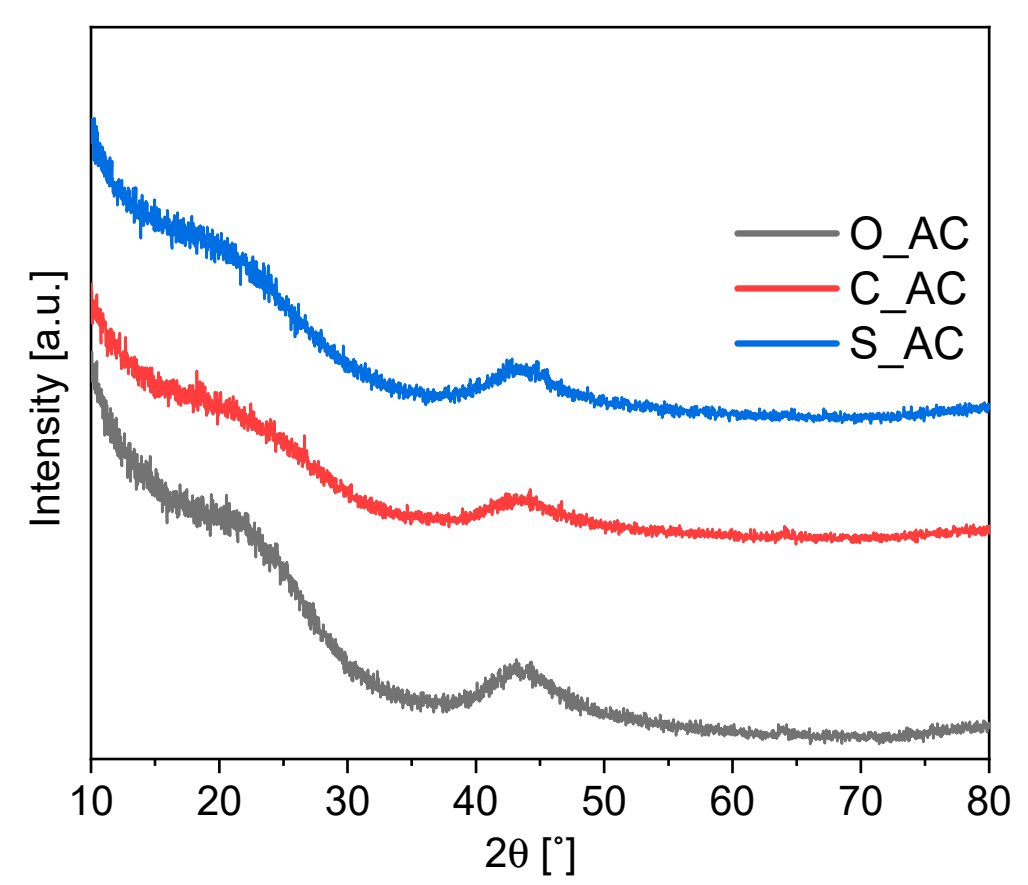

Figure 3. Diffractograms of activated carbons from biomass.

Diffractograms presented in Figure 3 show broad peaks, as well as the absence of a sharp peak. The absence of a sharp peak may indicate the amorphous structure of the materials. However, the occurrence of broad peaks (around $26^{\circ}$ and $43^{\circ}$ ) showed signs of the formation of a crystalline carbonaceous structure, resulting in better layer alignment [90]. A similar result was proposed by Jiang et al. [91] for bituminous coal as a precursor, by Martínez-Casillas et al. [92] for activated carbon from pecan nutshell, and by Wei et al. [30] in studies concerning the synthesis of carbon materials from orange peels.

SEM micrographs of the tested activated carbons samples are shown in Figure 4.

The SEM images show an irregular surface morphology. The surface of all carbonaceous materials from biomass was characterized by a well-developed structure, as evidenced by the presence of holes of various diameters and shapes. The (A1), (A2), (B1) and (B2) micrographs show a very similar picture of carbonaceous materials. Irregularly shaped holes are visible. Micrographs (C1) and (C2) showing activated carbon from sunflower husks are characterized by holes of a regular, oval shape. The presence of a porous structure facilitates the diffusion process indispensable in the heterogeneous catalysis for transport of both reactants and products. Fernandez et al. [28] and Wei et al. [30] obtained the activated carbon from orange peel with a similar morphology. Carbonaceous materials from coffee grounds obtained by Goncalves [40] and Pagalan [93] also showed a morphology similar to the surface morphology of the activated carbon obtained from coffee grounds characterized in this work. Moreover, the morphology of activated carbon from sunflower was similar to that described in the article of Saleh et al. [50].

The samples were characterized with the application of X-ray photoelectron spectroscopy (XPS). In Figure 5, the C 1s signals are presented. The deconvolution of the C $1 s$ signal allowed the quantitative analysis of carbon functional groups (Table 3). The detailed procedure of $\mathrm{C} 1 \mathrm{~s}$ deconvolution is described elsewhere [94]. 


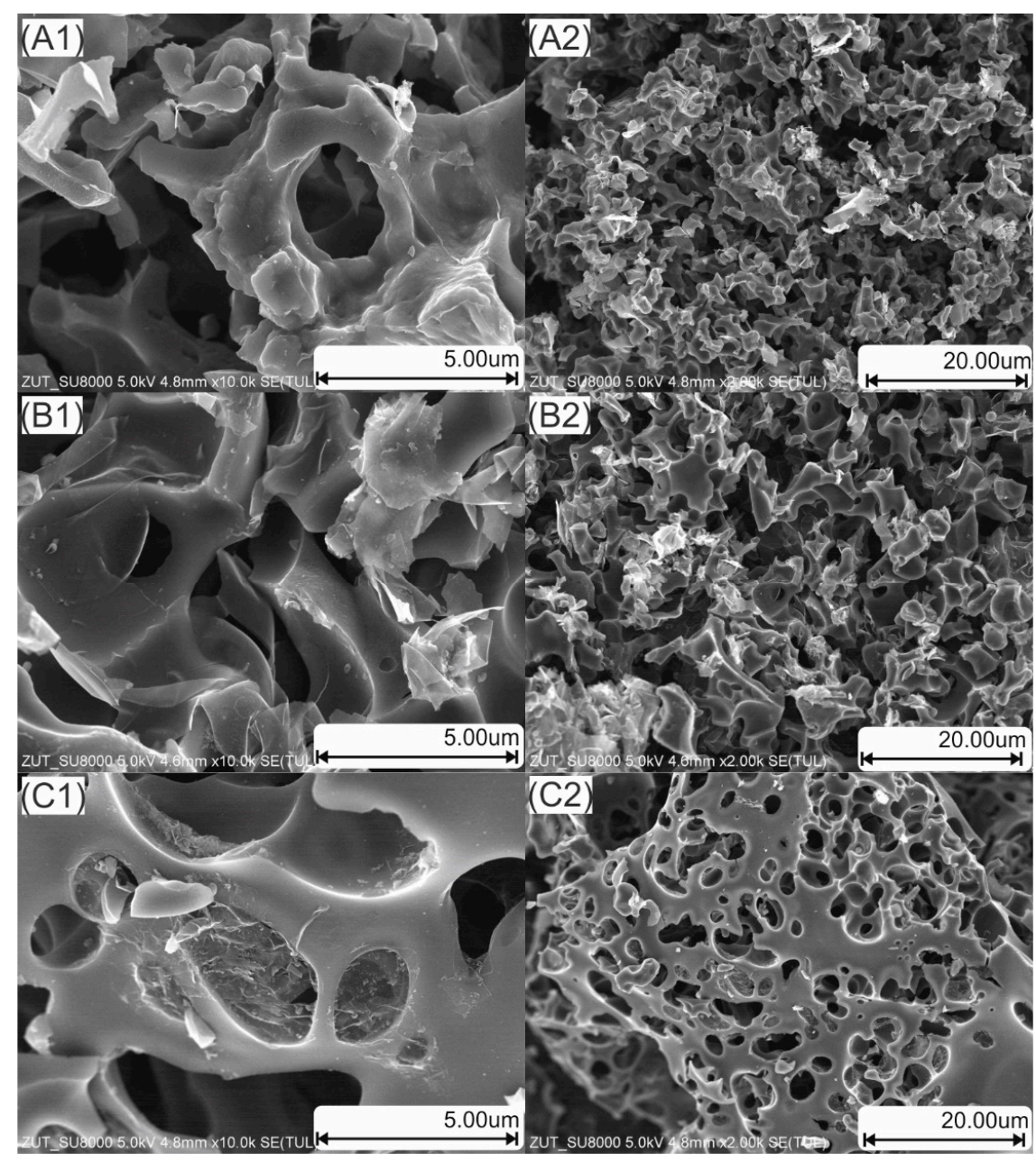

Figure 4. SEM micrographs of the activated carbons (A1,A2) - activated carbon from orange peels, (B1,B2)-activated carbon from coffee grounds, (C1, C2)-activated carbon from sunflower husks).

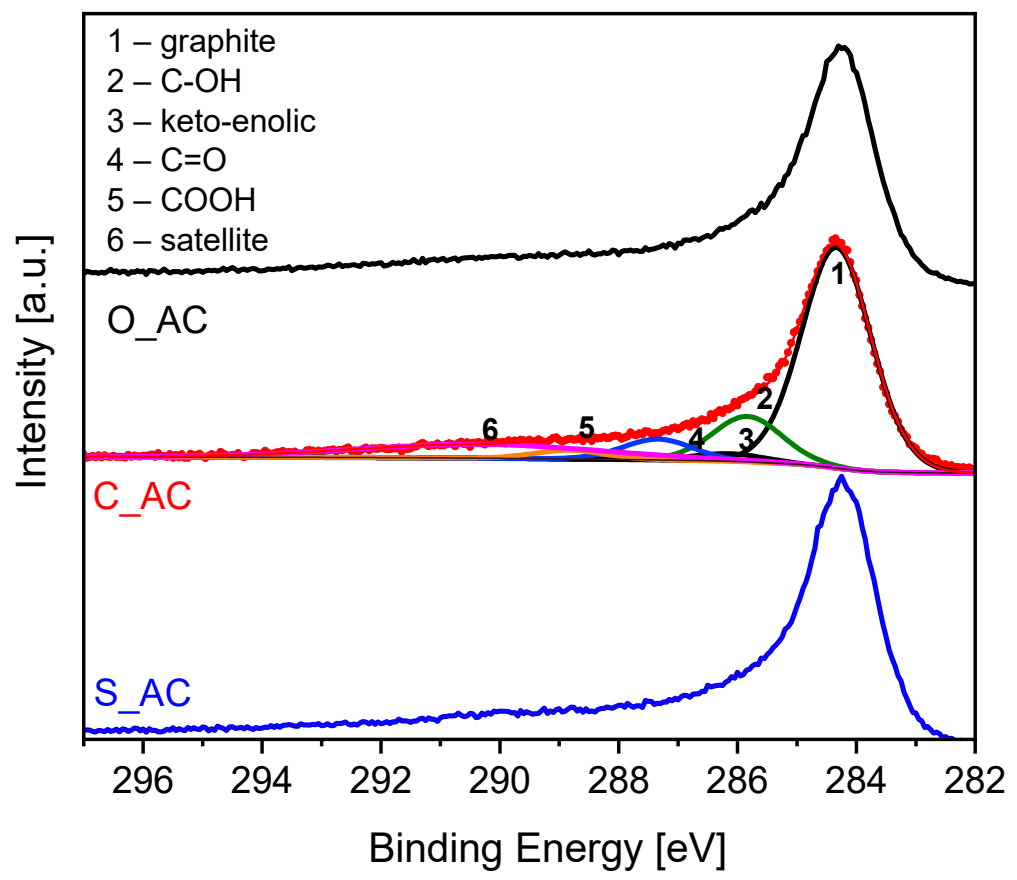

Figure 5. C 1s X-ray photoelectron spectra; the components are indicated for the C_AC sample. 
Table 3. The content of $\mathrm{C} 1 \mathrm{~s}$ components expressed as atomic concentrations.

\begin{tabular}{cccc}
\hline Assignment & O_AC & C_AC & S_AC \\
\hline C & 62.6 & 62.7 & 63.6 \\
C-O & 13.0 & 12.9 & 11.7 \\
Keto-enolic & 1.6 & 2.2 & 2.8 \\
C=O & 5.9 & 5.9 & 6.3 \\
COOH & 2.4 & 2.5 & 2.7 \\
Satellite & 14.6 & 13.9 & 12.8 \\
\hline
\end{tabular}

The material obtained from sunflower husks contained the lowest content of $\mathrm{C}-\mathrm{O}$ groups over the surface and the highest content of keto-enolic groups. The lowest content of keto-enolic groups characterized the material obtained from orange peels.

Figure 6 presents the $\mathrm{X}$-ray photoelectron spectra in the $0-1050 \mathrm{eV}$ energy range. The main signals are indicated over the spectra.

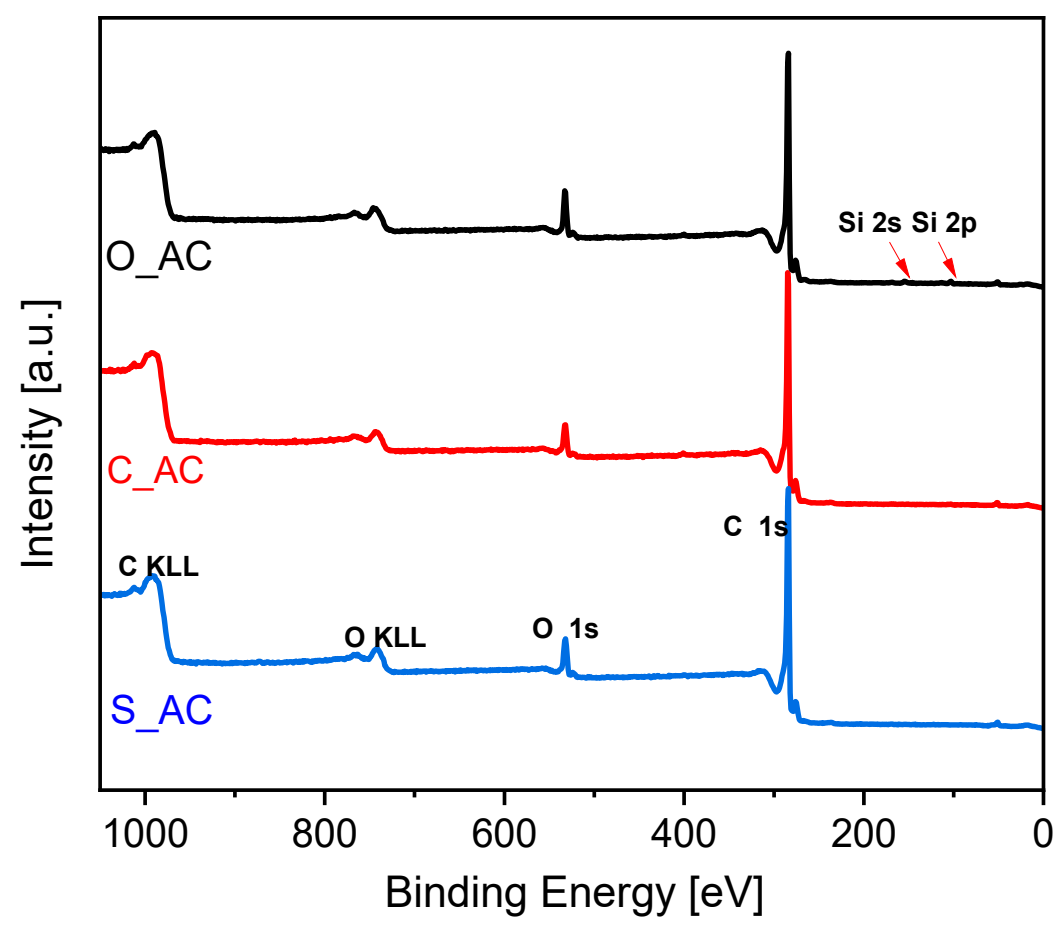

Figure 6. Survey X-ray photoelectron spectra.

The evaluation of the spectra enabled quantitative elemental analysis of the surface. The atomic concentrations of elements present over the surface are presented in Table 4 .

Table 4. The atomic concentrations of elements present over the surface of the obtained carbon materials.

\begin{tabular}{cccc}
\hline Sample & O 1s & C 1s & Si $2 p$ \\
\hline O_AC & 7.43 & 91.49 & 1.08 \\
C_AC & 5.89 & 93.78 & 0.33 \\
S_AC & 6.6 & 93.4 & 0 \\
\hline
\end{tabular}

In general, the elemental XPS analysis showed a high purity of obtained materials and low inorganic matter content over the surface. This is in line with XRD analysis where there was a lack of sharp reflexes typical for ash content (Figure 3). The XRF analysis showed the presence of other elements (Table 5). 
Table 5. Results obtained by XRF method for activated carbons obtained from orange peels, coffee grounds, and sunflower husks.

\begin{tabular}{cccccc}
\hline \multirow{2}{*}{ Sample } & \multicolumn{5}{c}{ Wt.\% } \\
\cline { 2 - 6 } & Si & S & Cl & K & Ca \\
\hline O_AC & 0.264 & 0.416 & 0.182 & 0.595 & 0.289 \\
C_AC & 0.268 & 0.244 & 0.696 & 0.997 & 0.000 \\
S_AC & 0.246 & 0.418 & 0.155 & 0.225 & 0.280 \\
\hline
\end{tabular}

However, XRF delivers the average elemental bulk concentration, whereas XPS shows the elemental surface concentration from c.a. $1 \mathrm{~nm}$ depth. Moreover, all elements other than carbon and oxygen detected by XRF were below $1 \mathrm{wt} . \%$ content.

\subsection{Activity of Activated Carbons}

In the first stage of the studies on the catalytic activity of the obtained activated carbons, the influence of the content of the appropriate activated carbon in the reaction mixture on the values of conversion and selectivity of the main products of alpha-pinene isomerization was investigated. The studies on catalytic activity were carried out under the following conditions: reaction time $3 \mathrm{~h}$, amount of alpha-pinene used in the reaction $3 \mathrm{~g}$, and temperature $160^{\circ} \mathrm{C}$. Figure 7 shows the effect of the O_AC catalyst content on the conversion of alpha-pinene and selectivity of major products.

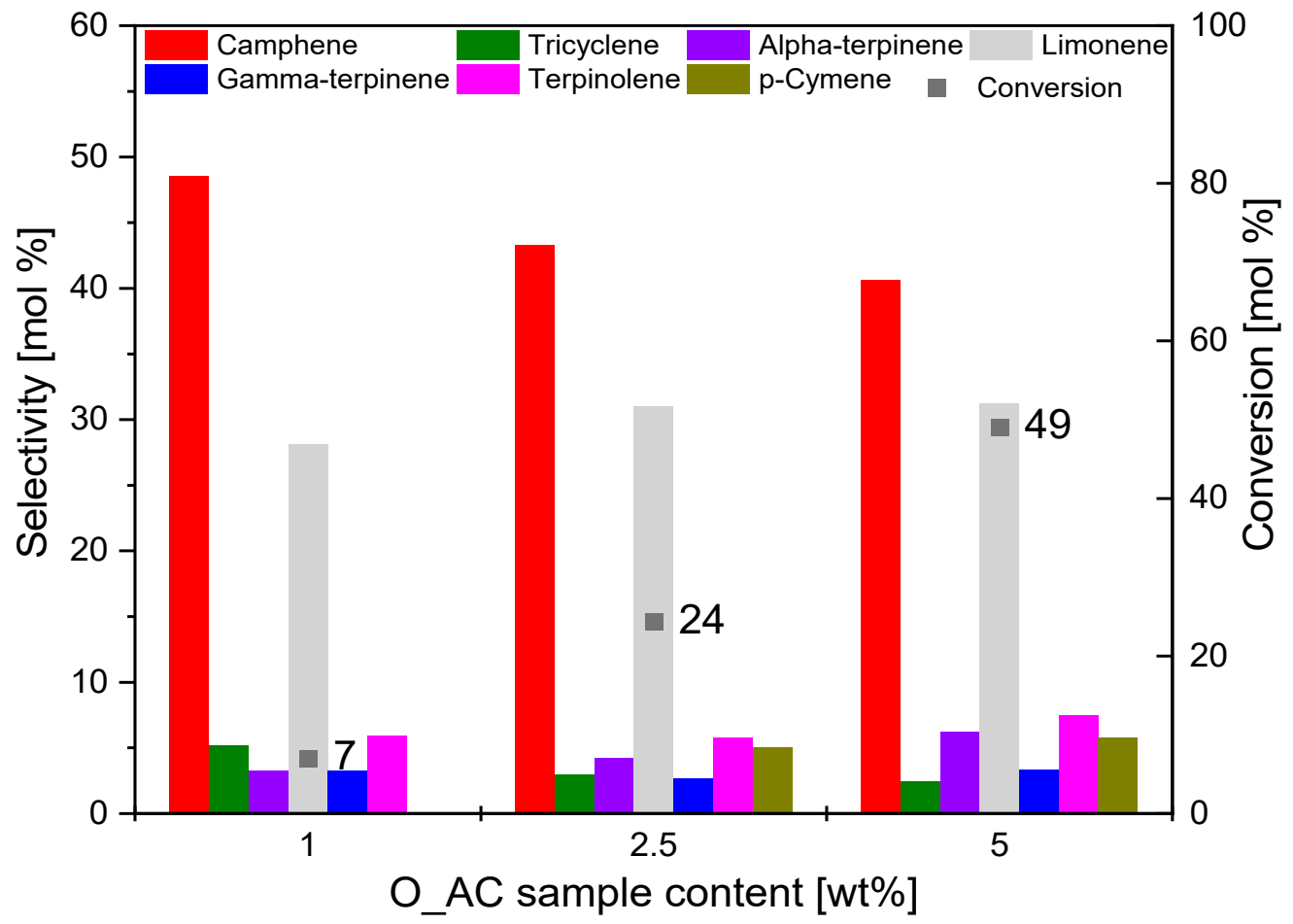

Figure 7. Influence of the O_AC sample content on the selectivity of the main products and conversion of organic raw material (alpha-pinene) after $3 \mathrm{~h}$.

It can be seen from Figure 7 that the conversion of alpha-pinene increased with increasing content of O_AC catalyst in the reaction mixture. The highest value of the conversion of alpha-pinene was recorded for the catalyst content of $5 \mathrm{wt} . \%$, and its was $49 \mathrm{~mol} . \%$.

The selectivity of the main reaction products (camphene and limonene) remained at a similar level across the whole range of studied catalyst content. We can say that the selectivity to camphene slightly decreased with increasing O_AC catalyst content in the reaction mixture (for O_AC sample content $1 \mathrm{wt} . \%$, it amounted to $48 \mathrm{~mol} . \%$, for O_AC 
sample content $2.5 \mathrm{wt} . \%$, it was $43 \mathrm{~mol} \%$, and, for O_AC sample content 5 wt. $\%$, it reached 41 mol.\%).

As the content of the O_AC catalyst in the reaction mixture increased, the value of selectivity of limonene increased only slightly. The selectivity of limonene amounted to $28 \mathrm{~mol} . \%$ for the catalyst content of $1 \mathrm{wt} . \%, 31 \mathrm{~mol} . \%$ for catalyst content of $2.5 \mathrm{wt} . \%$, and $32 \mathrm{~mol} . \%$ for catalyst content of $5 \mathrm{wt} . \%$. In addition to the main reaction products, the following products were formed in small amounts: tricyclene, terpinolene, gammaterpinene, and alpha-terpinene. Furthermore, $p$-cymene was not formed at the catalyst content of $1 \mathrm{wt}$.\%.

Figure 8 shows the effect of C_AC catalyst content on the conversion of the organic raw material (alpha-pinene) and selectivity of the main products.

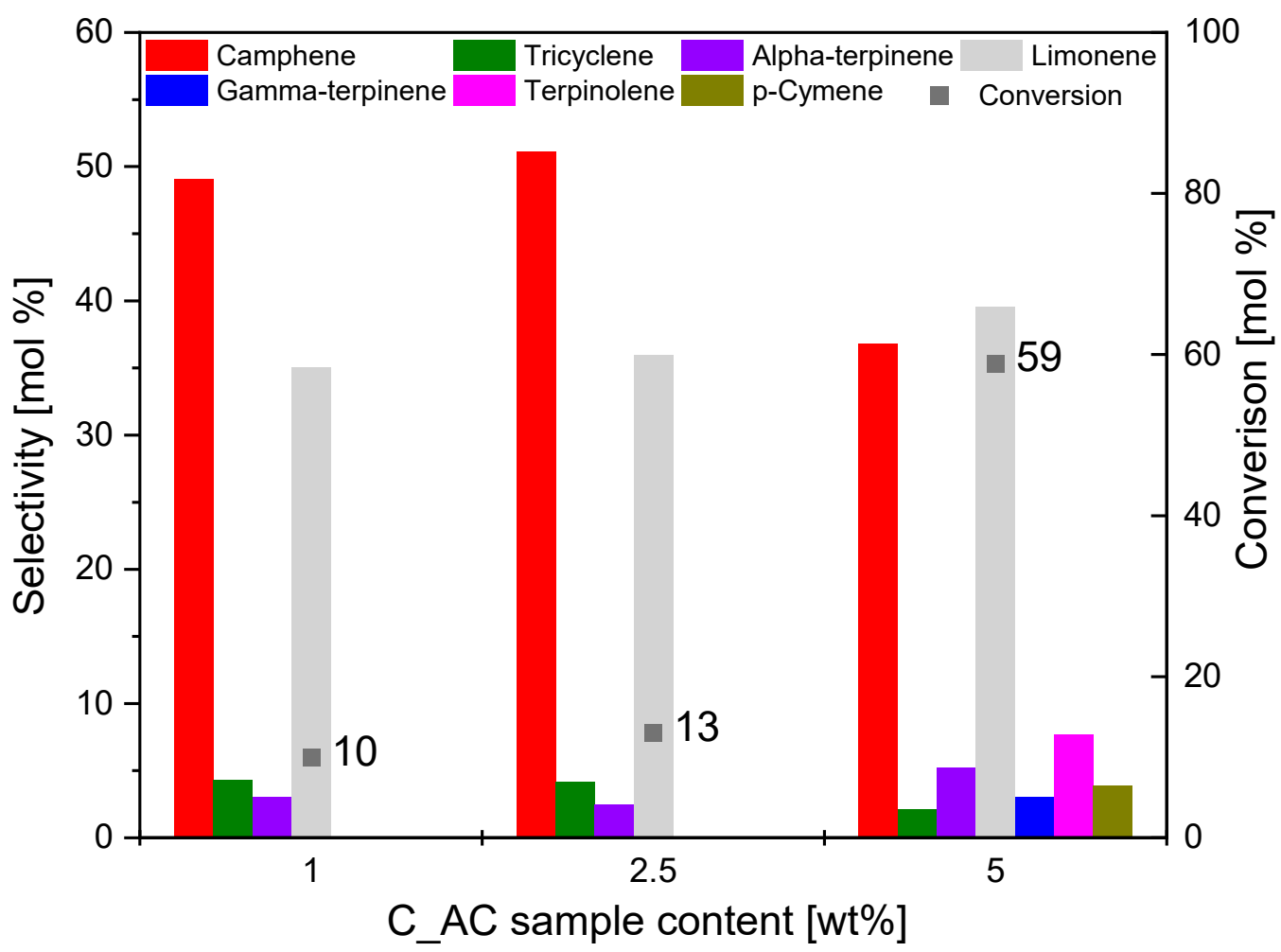

Figure 8. Influence of the C_AC sample content on the selectivity of the main products and conversion of organic raw material (alpha-pinene) after $3 \mathrm{~h}$.

It was noted that, with the increase in C_AC content in the reaction mixture, the conversion of alpha-pinene increased significantly (Figure 8). For the catalyst content of $5 \mathrm{wt} . \%$, the conversion was $59 \mathrm{~mol} \%$. This is because increasing the amount of catalyst increased the number of pores in which the isomerization reaction was most likely to occur, as described later. This allowed more alpha-pinene particles to enter in the pores and increased the conversion of this raw material. The highest value of selectivity of camphene was recorded for the catalyst content of $2.5 \mathrm{wt} . \%$, while the value of the conversion of alphapinene for this content of catalyst was relatively low (13 mol.\%). Selectivity to limonene for C_AC catalyst contents of $1 \mathrm{wt} . \%$ and $2.5 \mathrm{wt} . \%$ remained at a similar level and amounted to $30 \mathrm{~mol} . \%$ and $31 \mathrm{~mol} . \%$, respectively, whereas, for the content of $5 \mathrm{wt} . \%$, it was $40 \mathrm{~mol} \%$. For all catalyst contents, the formation of compounds such as alpha-terpinene and tricyclene with lower selectivity was noted. At a content of $5 \mathrm{wt} . \%, p$-cymene, terpinolene, and gamma-terpinene were also formed.

The effect of the catalyst content in the reaction mixture on the course of isomerization of alpha-pinene was also investigated for the S_AC sample. The results are shown in Figure 9 . 


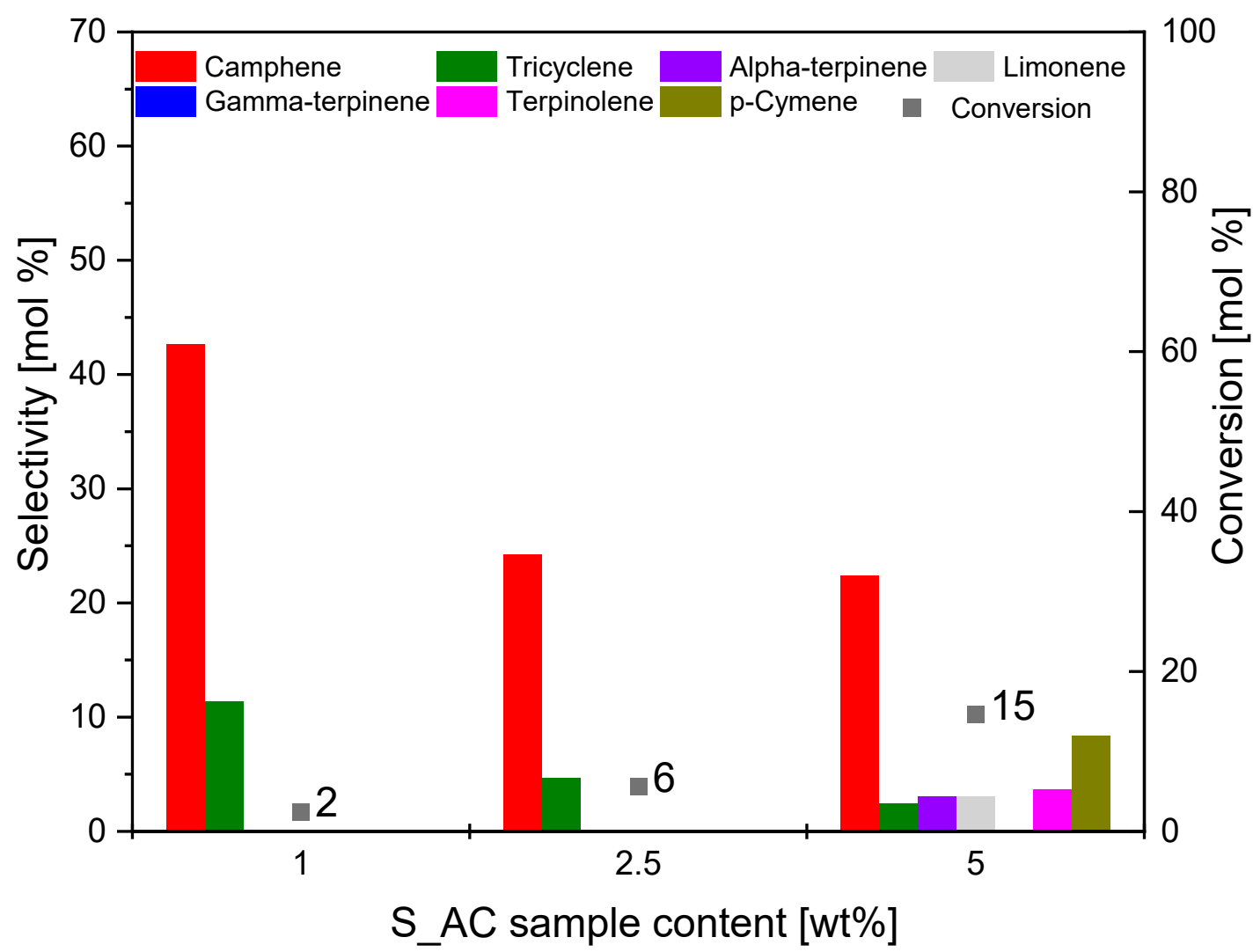

Figure 9. Influence of the S_AC sample content on the selectivity of the main products and conversion of organic raw material (alpha-pinene) after $3 \mathrm{~h}$.

It is visible from Figure 9 that increasing the S_AC catalyst content in the reaction mixture increased the value of conversion of alpha-pinene; for the content of the S_AC catalyst $5 \mathrm{wt} . \%$, the alpha-pinene conversion was $15 \mathrm{~mol} . \%$. It was found that the conversion of alpha-pinene was at the limit of the measurement error, and that the activated carbon from sunflower husks was not active for contents of $1 \mathrm{wt} . \%$ and $2.5 \mathrm{wt} . \%$. Only an increase in the catalyst content in the reaction mixture above $2.5 \mathrm{wt} . \%$ led to an increase in the conversion and selectivity to individual products.

For the S_AC catalyst content of $5 \mathrm{wt} . \%$, the selectivity of camphene was $22 \mathrm{~mol} . \%$. The byproduct formed with the highest selectivity was $p$-cymene ( 8 mol.\%). Limonene ( 3 mol. $\%$ ), alpha-terpinene ( $3 \mathrm{~mol} . \%)$, terpinolene $(4 \mathrm{~mol} . \%)$, and tricyclene ( $2 \mathrm{~mol} . \%)$ were also formed, but with less selectivity.

The tested catalysts showed different activity in the process we studied. As shown in our earlier publication [72], during alpha-pinene isomerization, we can observe two main pathways: path A where polycyclic compounds are formed (mainly camphene and tricyclene) and path B where monocyclic compounds (mainly limonene and terpinolene) are formed, whereby limonene and terpinolene can subsequently be isomerized or dehydrogenated. For the O_AC catalyst, we could observe both paths of transformation, with path A being the dominant one. Monocyclic products were formed in smaller amounts, but they were formed at each of the tested catalyst contents. On the other hand, $p$-cymene (the product of dehydration of these compounds) was formed only at the two highest catalyst contents. The results obtained with the C_AC catalyst were very similar in terms of the direction of transformation of alpha-pinene. However, only the application of the highest catalyst content allowed obtaining isomerization products of monocyclic compounds, as well as p-cymene. In the case of the S_AC catalyst, the test results indicate that path A of the alpha-pinene transformation was preferred, wherein camphene and tricyclene were formed with a slightly lower overall selectivity (about $5 \mathrm{~mol} . \%$ ) than in studies with previous cata- 
lysts. On the other hand, no limonene formation was observed; only with a catalyst content of $5 \mathrm{wt} . \%$ were only small amounts of limonene and terpinolene isomerization products detected in the post-reaction mixture. As with the previous two samples, $p$-cymene formation was only observed for the highest catalyst content in the reaction mixture. In research on this catalyst, the significantly lower alpha-pinene conversion compared to other catalysts (more than threefold) was also noticeable. Summarizing the research on the influence of the amount of the catalyst on the course of alpha-pinene isomerization, it can be said that, for all tested activated carbons, the content of $5 \mathrm{wt} . \%$ was the most advantageous.

In the next stage of the studies, the influence of temperature on the values of conversion of alpha-pinene and selectivity of products of the alpha-pinene isomerization process was investigated. For this purpose, the catalytic tests were carried out under the following conditions: reaction time $3 \mathrm{~h}$, amount of alpha-pinene used in the reaction $3 \mathrm{~g}$, content of catalyst $5 \mathrm{wt} . \%$, and temperature 140,160 , and $180^{\circ} \mathrm{C}$.

Figure 10 shows the effect of temperature on the isomerization process carried out in the presence of O_AC catalyst.

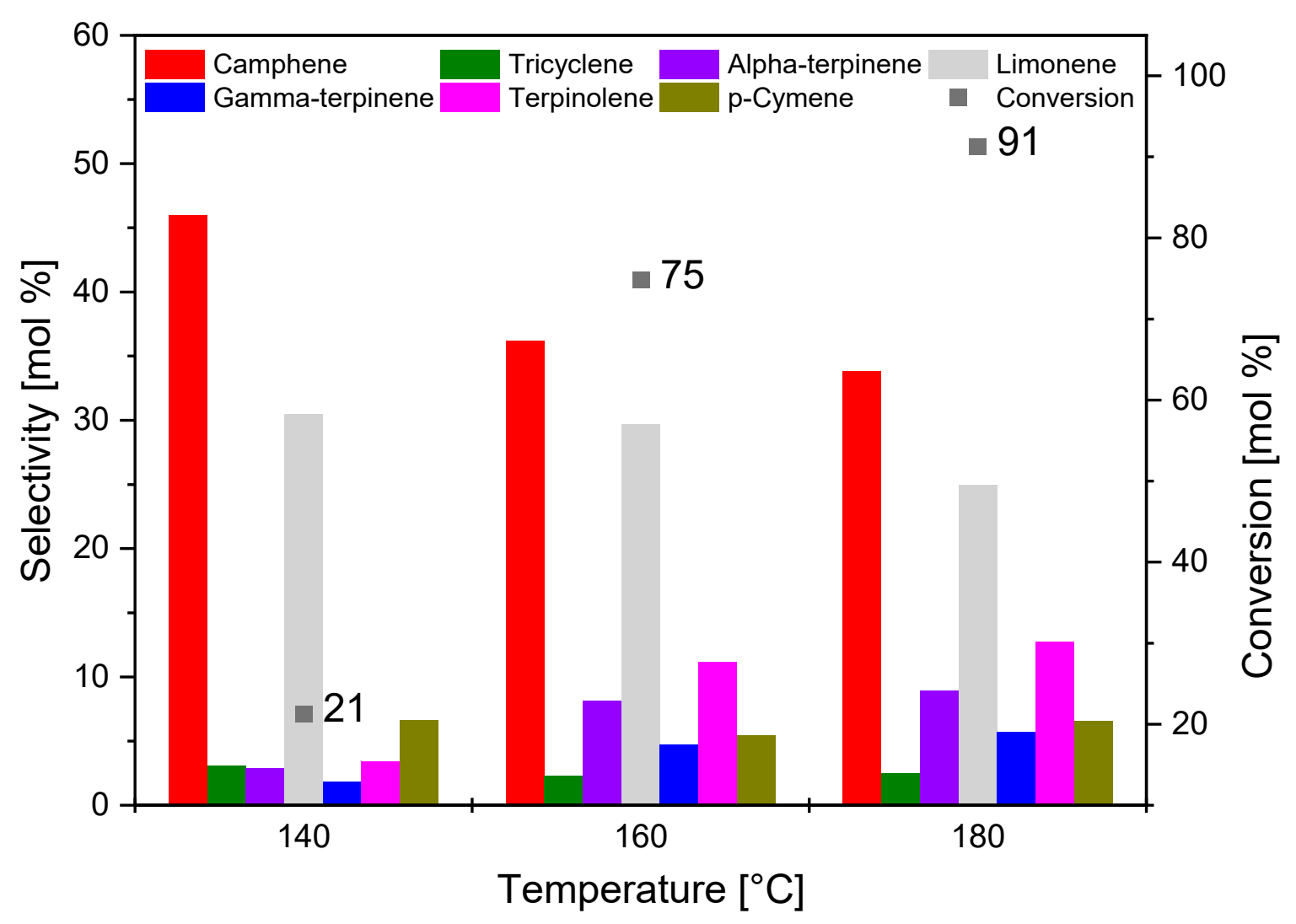

Figure 10. Comparison of the selectivity of the main products and the conversion of organic raw material (alpha-pinene) at different temperatures after $3 \mathrm{~h}$ for the O_AC sample.

It is visible from Figure 10 that the increase in temperature caused a marked increase in the value of conversion of alpha-pinene $\left(21 \mathrm{~mol} . \%\right.$ for $140{ }^{\circ} \mathrm{C}, 75 \mathrm{~mol} . \%$ for $160{ }^{\circ} \mathrm{C}$, and $91 \mathrm{~mol} . \%$ for $180^{\circ} \mathrm{C}$ ). This is due to the fact that increasing the temperature increased the diffusion rate of alpha-pinene molecules into the pores where the isomerization process took place, which in turn increased the conversion of this organic raw material.

It was noted that, as the reaction temperature increased, the values of selectivity of the main products decreased (from $41 \mathrm{~mol} . \%$ to $34 \mathrm{~mol} \%$ for camphene and from $30 \mathrm{~mol} \%$ to $25 \mathrm{~mol} \%$ for limonene). The decrease in selectivity of the main reaction products may be due to the fact that, with increasing temperature, an increase in the selectivity 
of transformation to byproducts of isomerization was visible. These byproducts were terpinolene, gamma-terpinene, $p$-cymene, and alpha-terpinene.

A comparison of the selectivity of the main products and the conversion of alphapinene using the C_AC catalyst at different temperatures is shown in Figure 11.

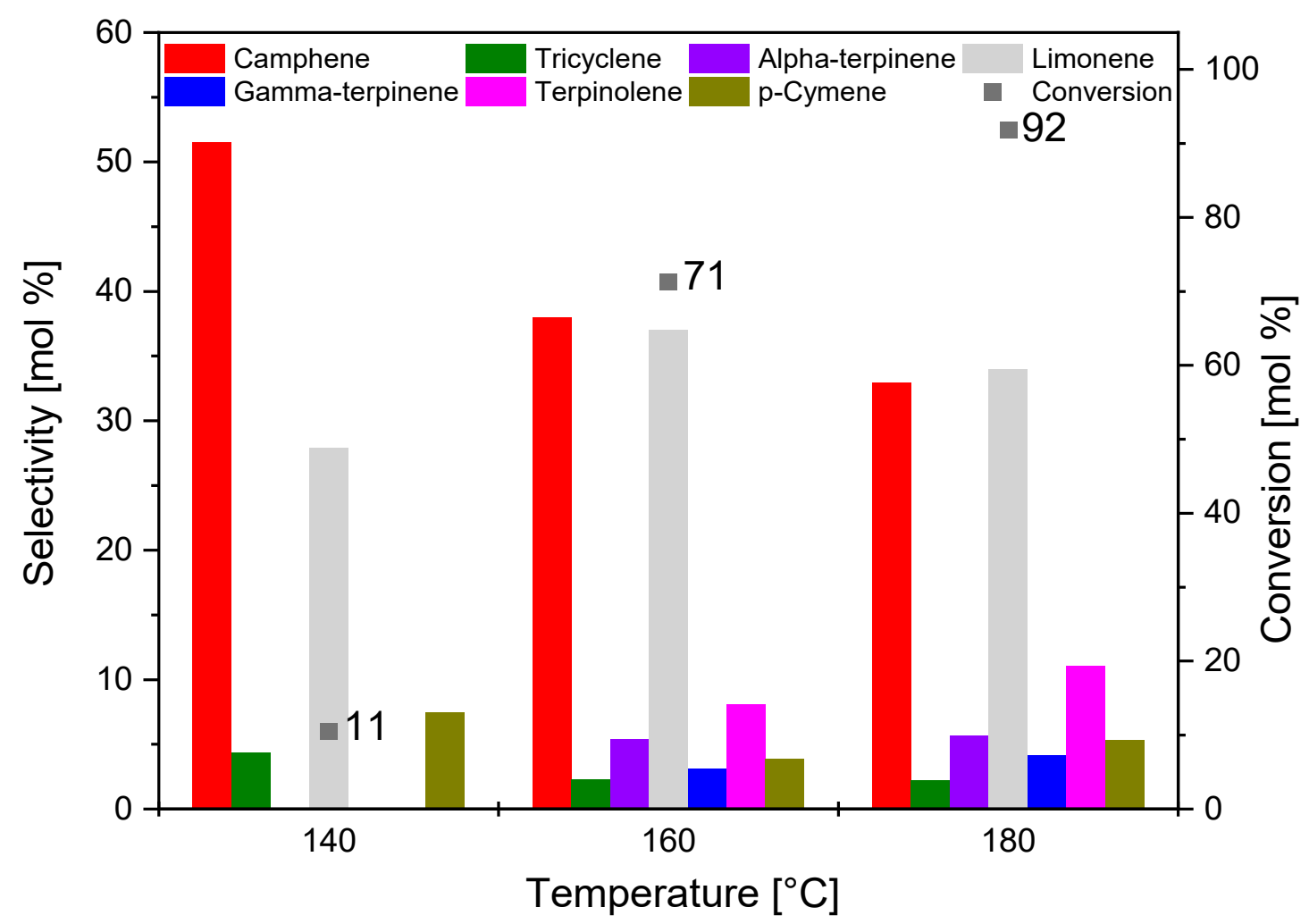

Figure 11. Comparison of the selectivity of the main products and the conversion of organic raw material (alpha-pinene) at different temperatures after $3 \mathrm{~h}$ for the C_AC sample.

Figure 11 shows that, with the increase in temperature, the conversion of alpha-pinene in the presence of C_AC catalyst increased to the maximum value of $92 \mathrm{~mol} . \%$ at the temperature of $180{ }^{\circ} \mathrm{C}$. The main reaction products, which were formed with similar selectivity at 160 and $180^{\circ} \mathrm{C}$, were camphene (35-38 mol.\%) and limonene (35-37 mol.\%). At $140{ }^{\circ} \mathrm{C}$, the slightly higher selectivity of camphene and low conversion of alpha-pinene (11 mol.\%) indicated a low reaction rate.

A comparison of the selectivity of the main products and the conversion of organic raw material (alpha-pinene) using the S_AC catalyst at different temperatures is shown in Figure 12. 


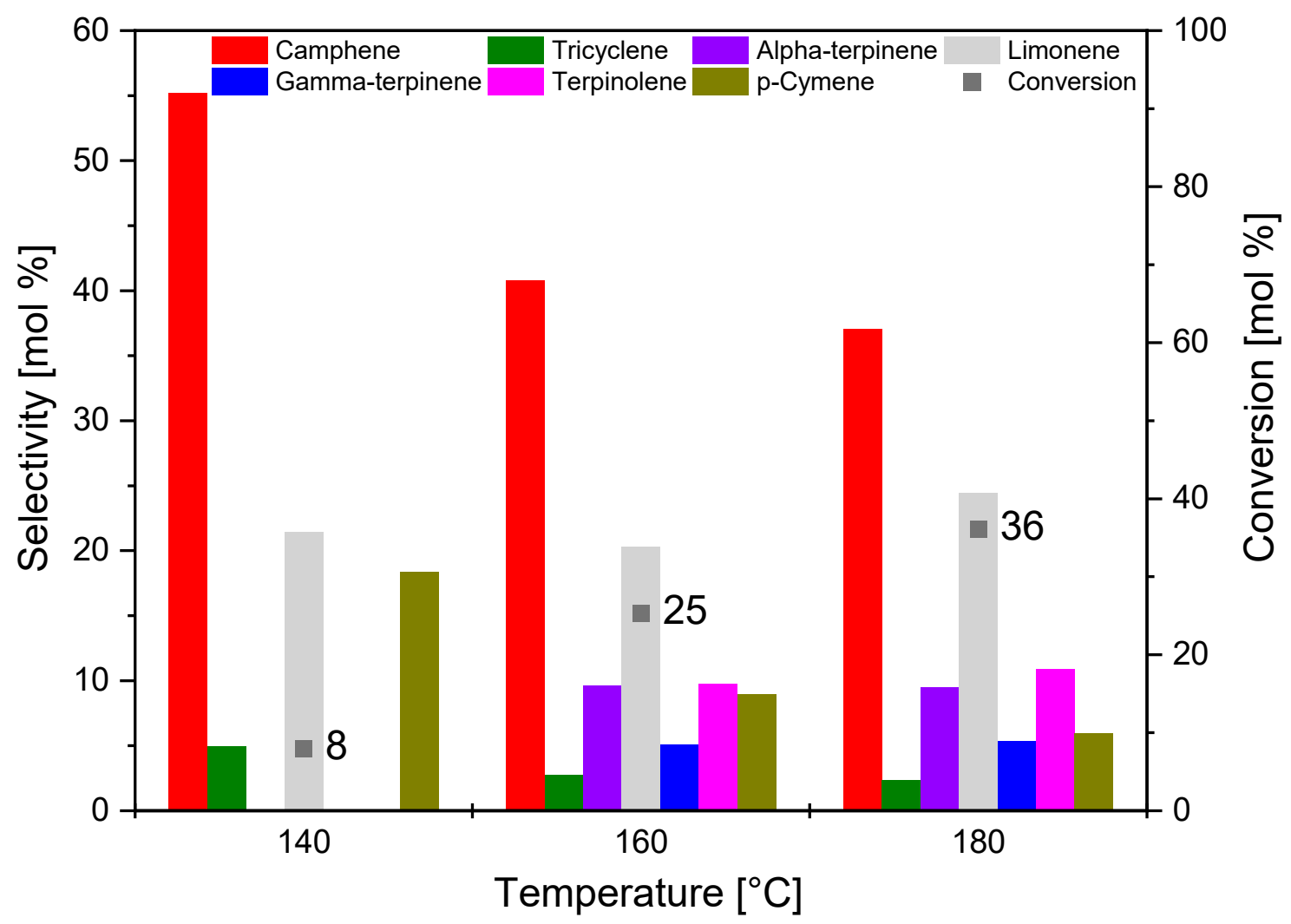

Figure 12. Comparison of the selectivity of the main products and the conversion of organic raw material (alpha-pinene) at different temperatures after $3 \mathrm{~h}$ for the S_AC sample.

The conversion of alpha-pinene for the reaction carried out at the temperature of $140{ }^{\circ} \mathrm{C}$ amounted to $8 \mathrm{~mol} . \%$ (Figure 12). It can be concluded that the process temperature of $140^{\circ} \mathrm{C}$ was too low, and the substrate reacted in a small amount. When using activated carbon from sunflower husks as the catalyst, the selectivity of camphene and $p$-cymene decreased with increasing temperature, while the selectivity of limonene and other products (terpinolene, gamma-terpinene, and alpha-terpinene) increased slightly.

Comparing the studies of the influence of temperature on the results obtained with the three tested catalysts, it can be said that the C_AC and S_AC catalysts were characterized by path $\mathrm{A}$ of alpha-pinene transformation being preferred at the lowest temperature. At this lowest temperature, the formation of $p$-cymene was also observed, which proves that the products formed along the path A were immediately transformed into $p$-cymene. Products produced according to path B appeared only at the two highest tested temperatures. Summarizing the studies on the influence of temperature on the course of alpha-pinene isomerization, the temperature of $160^{\circ} \mathrm{C}$ was considered the most favorable for all tested catalyst samples. This is due to the fact that, at $180{ }^{\circ} \mathrm{C}$, alpha-pinene boiled strongly and the selectivity to camphene and limonene decreased. This was caused by the subsequent reactions where limonene isomerized, and other products dimerized and polymerized. Further studies on the influence of reaction time on the course of isomerization and its kinetics were carried out at the temperature of $160^{\circ} \mathrm{C}$.

Figures 13-15 show the influence of reaction time on the course of isomerization of alpha-pinene at $160{ }^{\circ} \mathrm{C}$. For the reaction time effect study, $8 \mathrm{~g}$ of alpha-pinene and $0.4 \mathrm{~g}$ (5 wt.\%) of the appropriate catalyst (O_AC, C_AC, S_AC) was used. The test mixtures were collected in the range of $10-330 \mathrm{~min}$ at $30 \mathrm{~min}$ intervals. 


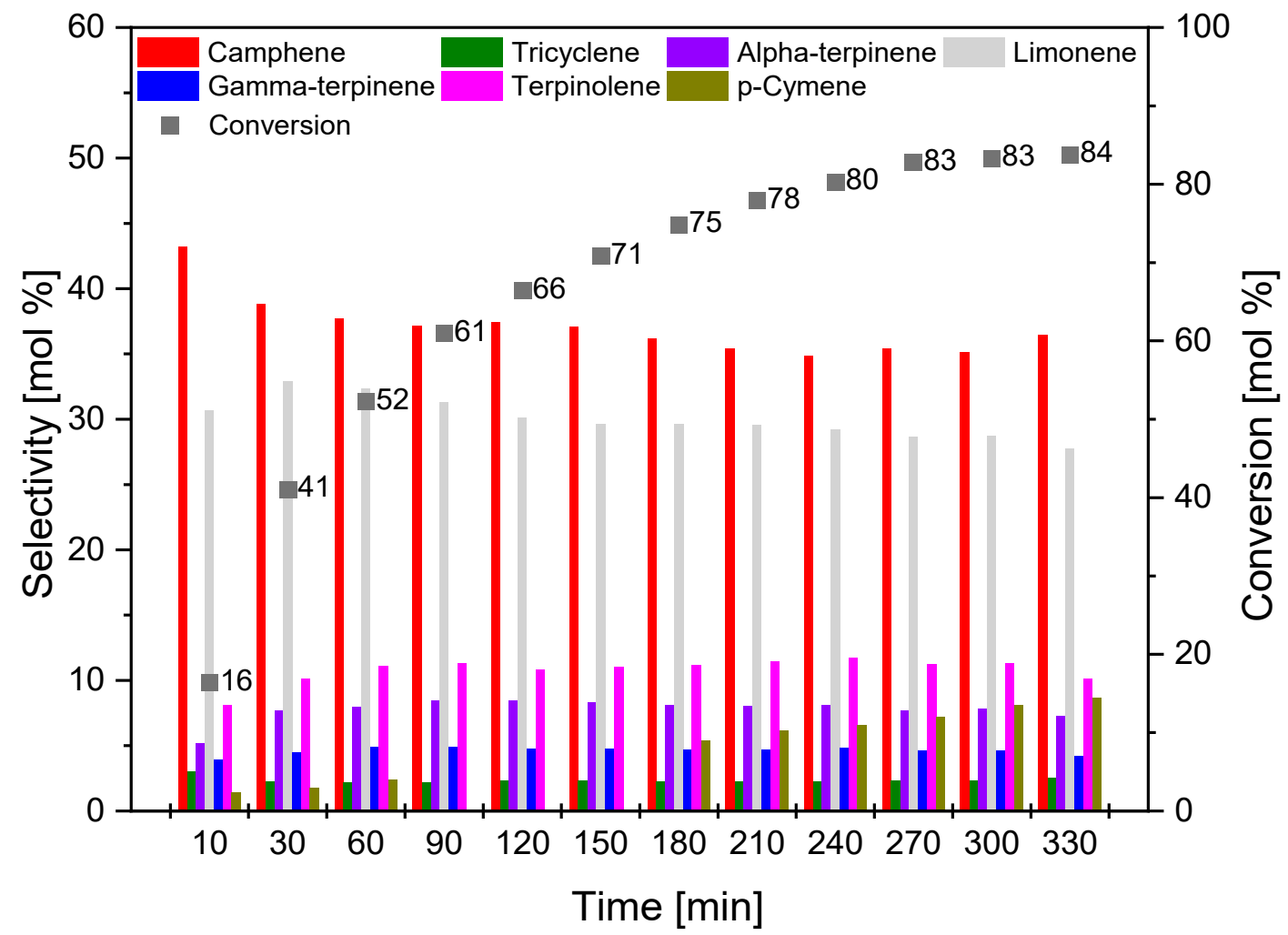

Figure 13. Influence of time on the selectivity of the main products and conversion of organic raw material (alpha-pinene) for O_AC sample.

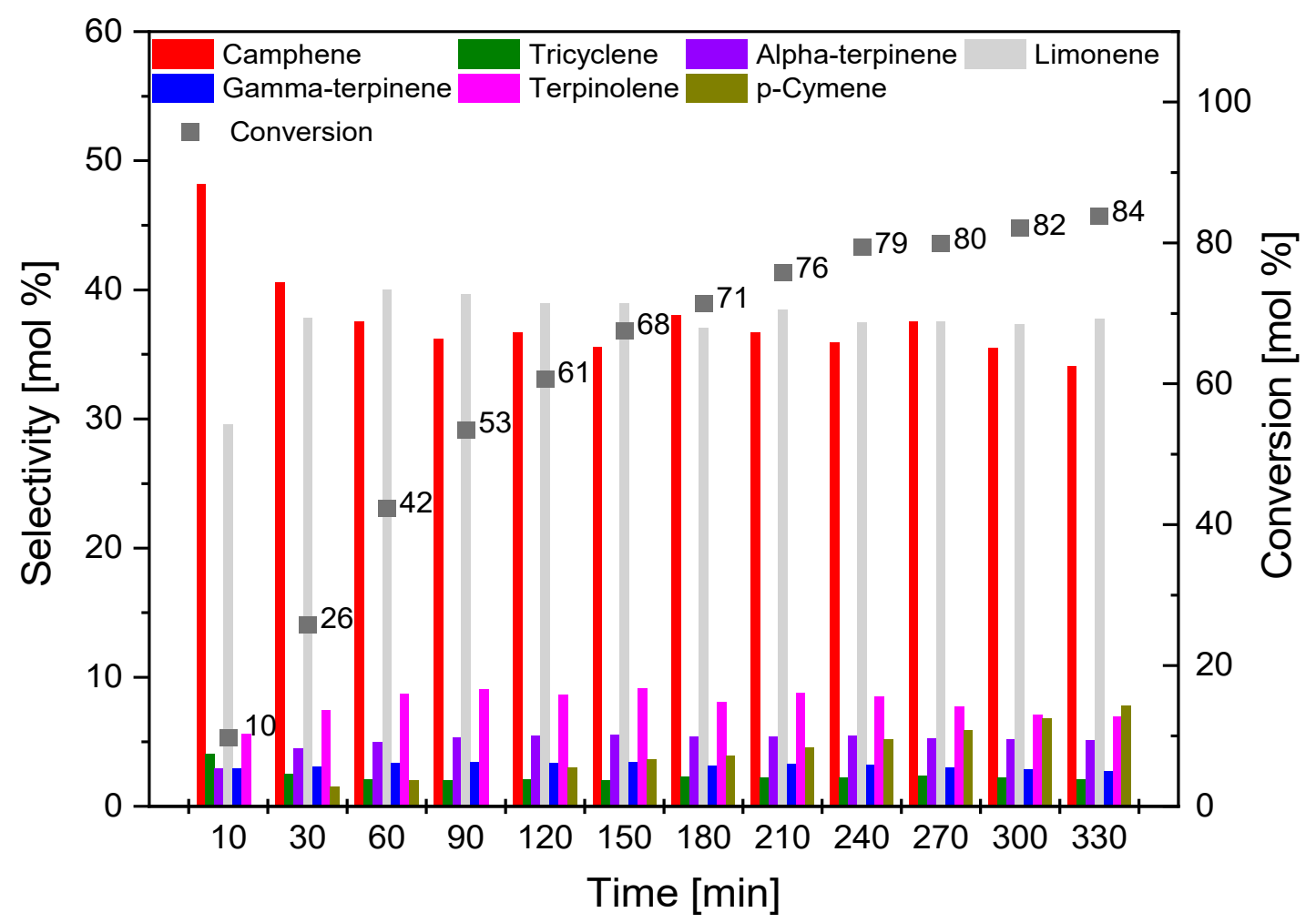

Figure 14. Influence of time on the selectivity of the main products and the conversion of organic raw material (alpha-pinene) for C_AC sample. 


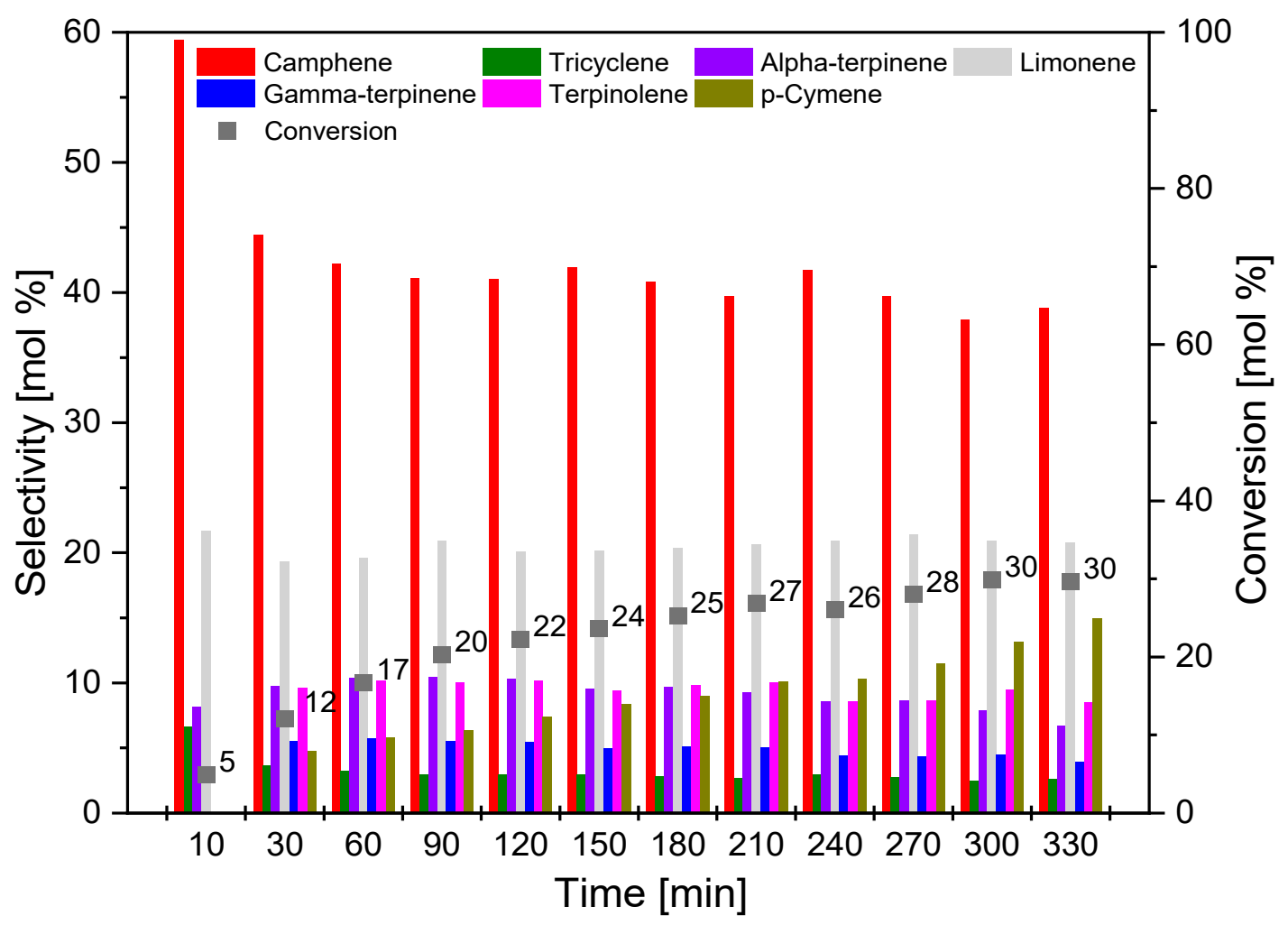

Figure 15. Influence of time on the selectivity of the main products and the conversion of organic raw material (alpha-pinene) for S_AC sample.

For catalyst $\mathrm{O}_{-} \mathrm{AC}$ (Figure 13), the selectivity of camphene was the highest for reaction time of $10 \mathrm{~min}$, while the conversion was relatively low (16 mol.\%). Over the duration of the process of isomerization, the selectivity to camphene decreased from $47 \mathrm{~mol} \%$ (time $10 \mathrm{~min}$ ) to $36 \mathrm{~mol} \%$ (time $300 \mathrm{~min}$ ). The selectivity of limonene was the highest for the reaction time of $30 \mathrm{~min}$ and amounted to $33 \mathrm{~mol} \%$, decreasing to $27 \mathrm{~mol} \%$ (reaction time $330 \mathrm{~min}$ ). The highest value of the conversion of alpha-pinene was obtained for a reaction time of $330 \mathrm{~min}$, and its was $84 \mathrm{~mol} \%$.

The isomerization carried out in the presence of the catalyst obtained from coffee grounds (C_AC; Figure 14) followed a similar course to the catalyst obtained from orange peels (O_AC). The selectivity of camphene was the highest for a reaction time of $10 \mathrm{~min}$, while the conversion of alpha-pinene was low (10 mol.\%). The selectivity of camphene decreased with prolongation of the reaction time; for the reaction time of $330 \mathrm{~min}$, it amounted to $34 \mathrm{~mol} . \%$. The selectivity of limonene remained similar throughout the reaction time studied. The highest value of the conversion of alpha-pinene for C_AC sample was obtained for a reaction time of $330 \mathrm{~min}$, and it was $84 \mathrm{~mol} . \%$.

Among all the activated carbons obtained from biomass, the activated carbon obtained from sunflower husks (S_AC; Figure 15) was characterized by the weakest activity in the studies on the influence of reaction time. The maximum conversion of alpha-pinene was achieved for a reaction time of $300 \mathrm{~min}$ (30 mol.\%). The selectivity of limonene remained similar throughout the studied reaction time and did not exceed $23 \mathrm{~mol} . \%$. The selectivity of camphene at the highest conversion of alpha-pinene was $38 \mathrm{~mol} . \%$.

The study of the influence of temperature showed that, despite the prolongation of the reaction time for the O_CA sample, the preferred direction of transformation was path A. In the case of the C_AC catalyst, the change of the privileged reaction to path B for reaction times over $30 \mathrm{~min}$ was noticeable (a higher total selectivity of the transformation to limonene and terpinolene with respect to camphene and tricyclene). In the case of sample 3 (S_AC), it is characteristic that path A was preferred to path B, and that the amount of $p$ - 
cymene produced in the reaction was significantly increased (this was especially noticeable when comparing the results for the S_AC sample with the results for the O_AC sample). Summarizing the studies on the influence of reaction time on the course of alpha-pinene isomerization for all tested catalyst samples, the time of $3 \mathrm{~h}$ was considered the most favorable. This time allowed obtaining high selectivity of camphene and limonene with relatively high alpha-pinene conversion.

Figure 16 shows a comparison of the catalytic activity of carbonaceous materials obtained from biomass. The most favorable conditions for all catalysts were as follows: content of catalyst $5 \mathrm{wt} . \%$, temperature $160^{\circ} \mathrm{C}$, and reaction time $3 \mathrm{~h}$.

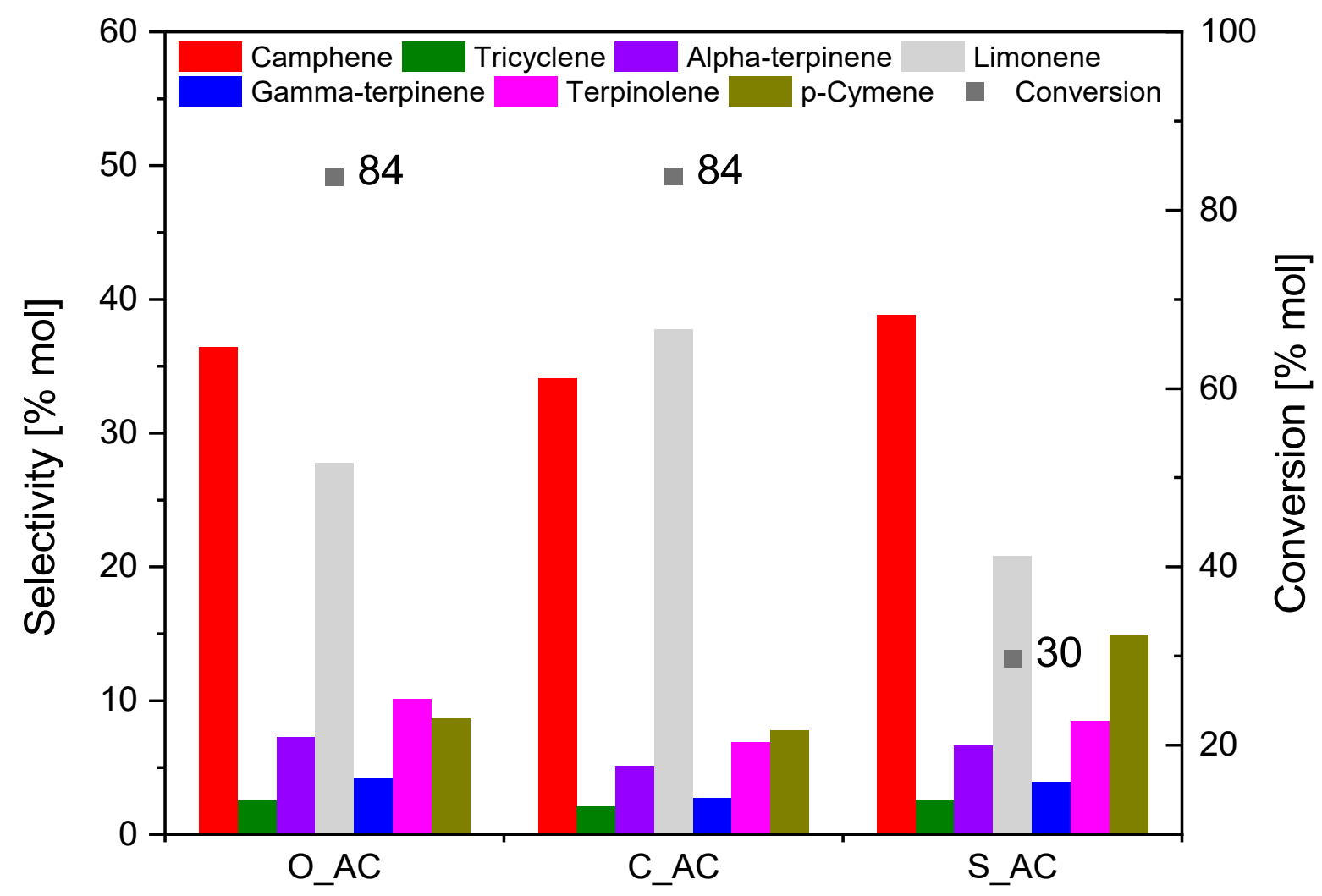

Figure 16. Comparison of the catalytic activity of activated carbons at the most favorable isomerization conditions (content of catalyst $5 \mathrm{wt} . \%$, temperature $160^{\circ} \mathrm{C}$, and reaction time $3 \mathrm{~h}$ ).

According to Figure 16, the most active catalyst in the isomerization process was activated carbon obtained from coffee grounds (C_AC), because the sum of selectivity of the main products (camphene and limonene) for the C_AC sample was the highest (72 mol.\%). For this catalyst, the conversion of alpha-pinene was $84 \mathrm{~mol} . \%$. Slightly worse results were obtained for the O_AC catalyst, with a comparable conversion of alpha-pinene but a lower sum of selectivity of camphene and limonene (64 mol.\%).

On the other hand, activated carbon obtained from sunflower husks (S_AC) was characterized by the lowest catalytic activity, which makes it an unfavorable catalyst for the alpha-pinene isomerization process. The conversion of alpha-pinene for the S_AC material was only $30 \mathrm{~mol} . \%$, and the sum of selectivity of camphene and limonene amounted to $60 \mathrm{~mol} . \%$.

Comparing the textural properties of the three tested catalysts (presented in Table 2), it can be seen that the C_AC sample was characterized by the largest specific surface area $\left(1566 \mathrm{~m}^{2} / \mathrm{g}\right)$ and the largest micropore volume $\left(0.540 \mathrm{~cm}^{3} / \mathrm{g}\right)$ among the tested catalysts. Smaller values of these two values were obtained for the sample designated as O_AC $\left(1416 \mathrm{~m}^{2} / \mathrm{g}\right.$ and $\left.0.482 \mathrm{~cm}^{3} / \mathrm{g}\right)$. Additionally, the proportion of mesopores in the O_AC sample was largest for the apparent pore range of $2.7 \mathrm{~nm}$. The values obtained for the S_AC 
sample significantly differed from the values obtained for the other two samples. This difference in the textural parameters characterizing the tested three samples of activated carbons probably led to the carbons obtained from coffee grounds and orange peels being the most active.

Taking into account the pore size of the tested samples (Figure 2, Table 2), i.e., $0.4-0.7 \mathrm{~nm}, 0.7-1.0 \mathrm{~nm}, 1.1-1.4 \mathrm{~nm}$, and $1.5-2.5 \mathrm{~nm}$, and the number of pores, we can conclude that the C_AC and O_AC samples had the largest number of pores with a size of $0.7-1.0,1.1-1.4 \mathrm{~nm}$ and $1.5-2.5 \mathrm{~nm}$, whereas the S_AC sample had the largest number of pores with a size of $0.4-0.7 \mathrm{~nm}$. The size of the alpha-pinene molecule is about $0.7 \mathrm{~nm}$ [95]; thus, pores with a size of $0.7-1.0$ and 1.1-1.4 $\mathrm{nm}$ or larger are of greatest importance for the isomerization process of this compound. The results in Figure 2, thus, confirm that the catalyst samples C_AC and O_AC allowed diffusion of alpha-pinene molecules into the interior of the pores, where the investigated reaction took place, and that these catalyst samples should be the most active in the process. In addition, the results presented in Table 2 for pore volumes of $0.73-1 \mathrm{~nm}$ and $1-2 \mathrm{~nm}$ for the O_AC and C_AC samples show that C_AC activated carbon had a greater number of pores with a pore size of $0.73-1 \mathrm{~nm}$ (volumes of $0.123 \mathrm{~cm}^{3} / \mathrm{g}$ and $0.097 \mathrm{~cm}^{3} / \mathrm{g}$, respectively), which probably determined the slight difference in the activity of O_AC and C_AC catalysts, in favor of the latter.

The acidity studies summarized in Table 2 indicate that, in the case of alpha-pinene isomerization, surface acidity did not affect the final activity of the catalyst, as the highly acidic sample of S_AC turned out to be inactive. The answer to why the catalyst sample obtained from sunflower husk was the least active may be reflected in the results of XRF tests. Therefore, the instrumental tests of the catalysts were supplemented with XRF tests. The results of these studies are presented in Table 5.

Table 5 shows that the tested samples of carbon materials differed significantly in the content of $\mathrm{S}, \mathrm{Cl}$, and $\mathrm{K}$. The $\mathrm{C} \_\mathrm{AC}$ sample was characterized by a significantly higher content of $\mathrm{Cl}$ and $\mathrm{K}$ compared to the O_AC sample. It can be initially assumed that the abovementioned elements, most likely $\mathrm{K}^{+}$and $\mathrm{Cl}^{-}$ions, present in the pores of the tested active carbons, are of key importance for the alpha-pinene isomerization process. However, this requires further research.

\subsection{Determination of the Kinetics Parameters}

The overall kinetic studies of $\alpha$-pinene isomerization over three activated carbons was performed for several order reactions, using a parameter estimation software based on the following equations:

First-order reaction:

$$
-\frac{\mathrm{dC}_{\alpha-\text { pinene }}}{\mathrm{dt}}=\mathrm{kC}_{\alpha-\text { pinene }}
$$

Different reaction orders:

$$
\frac{\mathrm{C}_{\mathrm{A}}^{1-\mathrm{n}}-\mathrm{C}_{\mathrm{A}_{0}}^{1-\mathrm{n}}}{\mathrm{n}-1}=\mathrm{kt},
$$

where $\mathrm{C}_{\alpha \text {-pinene }}$ is the alpha-pinene concentration, $\mathrm{t}$ is the reaction time, and $\mathrm{k}$ is the reaction rate constant.

According to the regression coefficients, it was concluded that $\alpha$-pinene isomerization is a first-order reaction. This reaction order followed our early studies obtained for $\alpha$-pinene isomerization over $\mathrm{Ti}_{3} \mathrm{C}_{2}$ and ex- [96] and clinoptilolite (modified with $0.1 \mathrm{M} \mathrm{H}_{2} \mathrm{SO}_{4}-\mathrm{CLIN}$ 0.1) [66]. Similar results were also evidenced by other authors, e.g., Ünveren et al. [65] and Allahverdiev et al. [97].

The determined reaction rate coefficients for the first-order reaction are compiled in Table 6. 
Table 6. The $\alpha$-pinene isomerization kinetic parameters.

\begin{tabular}{ccc}
\hline Sample & $\mathbf{k}\left(\mathbf{h}^{-\mathbf{1}}\right)$ & $\boldsymbol{R}^{\mathbf{2}}$ \\
\hline O_AC & 0.3178 & 0.9309 \\
C_AC & 0.3311 & 0.9670 \\
S_AC & 0.0573 & 0.9049 \\
\hline
\end{tabular}

The reaction rate constant calculated for $\alpha$-pinene isomerization over the activated carbons derived from coffee grounds achieved the highest value equal to $0.3311 \mathrm{~h}^{-1}$, which is over sixfold higher than the calculated constant calculated for $\alpha$-pinene isomerization over the activated carbons obtained from sunflower husks $\left(k=0.47 \mathrm{~h}^{-1}\right)$.

The reaction network of the suggested mechanism of $\alpha$-pinene isomerization over the activated carbons was the same as that over clinoptilolite. The advanced network of $\alpha$-pinene isomerization is shown in Table 7.

Table 7. Reaction mechanism for $\alpha$-pinene isomerization.

\begin{tabular}{|c|c|c|c|c|c|c|c|c|c|}
\hline No. & Steps & $\begin{array}{l}\alpha \text {-Pinene = } \\
\text { Tricyclene }\end{array}$ & $\begin{array}{l}\alpha \text {-Pinene = } \\
\text { Camphene }\end{array}$ & $\begin{array}{l}\alpha \text {-Pinene }= \\
\text { Limonene }\end{array}$ & $\begin{array}{c}\alpha \text {-Pinene }= \\
\alpha+\gamma- \\
\text { Terpinene }\end{array}$ & $\begin{array}{c}\alpha \text {-Pinene }= \\
\text { Terpino- } \\
\text { lene }\end{array}$ & $\begin{array}{c}\text { Limonene } \\
= \\
p \text {-Cymene }\end{array}$ & $\begin{array}{c}\alpha+\gamma- \\
\text { Terpinene } \\
= \\
p \text {-Cymene }\end{array}$ & $\begin{array}{c}\text { Terpinolene } \\
= \\
p \text {-Cymene }\end{array}$ \\
\hline 1 & $Z+A \Xi Z \cdot(A)$ & 1 & 1 & 1 & 1 & 1 & 0 & 0 & 0 \\
\hline 2 & $Z \cdot(\mathrm{A}) \Rightarrow Z \cdot(\mathrm{A})_{1}$ & 1 & 1 & 0 & 0 & 0 & 0 & 0 & 0 \\
\hline 3 & $\mathrm{Z} \cdot(\mathrm{A}) \Rightarrow \mathrm{Z} \cdot(\mathrm{A})_{2}$ & 0 & 0 & 1 & 1 & 1 & 0 & 0 & 0 \\
\hline 4 & $\mathrm{Z} \cdot(\mathrm{A})_{1} \Leftrightarrow \mathrm{Z} \cdot(\mathrm{B})$ & 1 & 0 & 0 & 0 & $\frac{1}{0}$ & 0 & 0 & 0 \\
\hline 5 & $\mathrm{Z} \cdot(\mathrm{A})_{1} \Leftrightarrow \mathrm{Z} \cdot(\mathrm{C})$ & 0 & 1 & 0 & 0 & 0 & 0 & 0 & 0 \\
\hline 6 & $\mathrm{Z} \cdot(\mathrm{B}) \Xi Z+\mathrm{B}$ & 1 & 0 & 0 & 0 & 0 & 0 & 0 & 0 \\
\hline 7 & $Z \cdot(C) \Xi Z+C$ & 0 & 1 & 0 & 0 & 0 & 0 & 0 & 0 \\
\hline 8 & $\mathrm{Z} \cdot(\mathrm{A})_{2} \Rightarrow \mathrm{Z} \cdot(\mathrm{D})$ & 0 & 0 & 1 & 0 & 0 & 0 & 0 & 0 \\
\hline 9 & $Z \cdot(\mathrm{D}) \Xi Z+D$ & 0 & 0 & 1 & 0 & 0 & -1 & 0 & 0 \\
\hline 10 & $\mathrm{Z} \cdot(\mathrm{A})_{2} \Rightarrow \mathrm{Z} \cdot(\mathrm{E})$ & $\underline{0}$ & 0 & 0 & 1 & 0 & 0 & 0 & 0 \\
\hline 11 & $Z \cdot(\mathrm{E}) \Xi Z+(\mathrm{E})$ & $\overline{0}$ & 0 & 0 & 1 & 0 & 0 & -1 & 0 \\
\hline 12 & $\mathrm{Z} \cdot(\mathrm{A})_{2} \Rightarrow \mathrm{Z} \cdot(\mathrm{F})$ & 0 & 0 & 0 & 0 & 1 & 0 & 0 & 0 \\
\hline 13 & $Z \cdot(F) \Xi Z+F$ & 0 & 0 & 0 & 0 & 1 & 0 & 0 & -1 \\
\hline 14 & $Z \cdot(\mathrm{D}) \Rightarrow Z \cdot(\mathrm{G})$ & 0 & 0 & 0 & 0 & 1 & 0 & 0 & 0 \\
\hline 15 & $Z \cdot(E) \Rightarrow Z \cdot(G)$ & 0 & 0 & 0 & 0 & 0 & 0 & 1 & 0 \\
\hline 16 & $Z \cdot(F) \Rightarrow Z \cdot(G)$ & 0 & 0 & 0 & 0 & 0 & 0 & 0 & 1 \\
\hline 17 & $Z \cdot(G) \Xi G$ & 0 & 0 & 0 & 0 & 0 & 0 & 0 & 1 \\
\hline
\end{tabular}

Note. $\mathrm{A}-\alpha$-pinene, $\mathrm{B}$-tricyclene, $\mathrm{C}$-camphene, $\mathrm{D}-$ limonene, $\mathrm{E}-\alpha+\gamma$-terpinene, $\mathrm{F}$-terpinolene, $\mathrm{G}-p$-cymene, $\mathrm{Z}$ surface sites.

An accurate reaction mechanism is a crucial element of reliable modeling. The advanced reaction mechanism was expressed by eight reaction routes, compiled in columns. Chemical equations of the basic and intermediate steps, including reactants and surface species, were placed in 17 rows.

Even when information is available, identifying the relevant data from the variety of numbers can be a difficult process without help. Thus, in order to explain the significance of 1,0 , and -1 values, a brief explanation is provided for Table 7: 1 is connected with the appearance of the order of a basic reaction which must lead from reactants to products, e.g., 1 (denoted by bold and underlined font at the crossing of 3 row and 5 column) indicates that $\alpha$-pinene leads to terpinolene just when it is maintained by an irreversible arrangement of $Z$-( $\alpha$-pinene $)_{2}$ from $Z$-( $\alpha$-pinene); 0 indicates that a reaction equation described in a row is not interconnected with a product placed in a column, e.g., $\mathbf{0}$ (bold and underlined font at the crossing of 10 row and 1 column) implies that this is unlikely to lead to tricyclene from $Z$-( $\alpha$-pinene $)_{2}$ or $(\alpha+\gamma$-terpinene) because both pathways are not connected; -1 relates to a reaction wherein an intermediary product is utilized as a final product in one step, e.g., $\mathbf{- 1}$ (bold and underlined font at the intersection of 13 row and 8 column) signifies that $p$ cymene as a final product is produced in one step from terpinolene (intermediate product).

Completed kinetic modeling with the detailed derivation and parameter estimation for a system of differential equations was developed. However, in this paper, we present just some of the results. We rearranged the kinetic equations (a system of differential reactions directly incorporating time-dependent concentrations) for an analysis of selectivity dependence. Parameter calculation was achieved similarly to [65] utilizing Miniwork 
software. The system of differential Equations (3)-(6) was combined at each minimization step with the following aim function: sum of squares of determined and empirical values of mole fraction.

$$
\begin{gathered}
-\frac{d C_{B}}{d C_{A}}=f_{1}+f_{2} \frac{C_{C}}{C_{A}}-f_{3} \frac{C_{B}}{C_{A}} . \\
-\frac{d C_{C}}{d C_{A}}=f_{4}-f_{2} \frac{C_{C}}{C_{A}}+f_{3} \frac{C_{B}}{C_{A}} . \\
-\frac{d C_{D}}{d C_{A}}=f_{5}-f_{6} \frac{C_{D}}{C_{A}} . \\
-\frac{d C_{G}}{d C_{A}}=f_{7} \frac{C_{D}}{C_{A}}+f_{8} \frac{C_{E}}{C_{A}}+f_{9} \frac{C_{F}}{C_{A}} .
\end{gathered}
$$

For subsequent modeling, one assumption was proposed: the rates corresponding to camphene and tricyclene $(1 \rightarrow 2 \rightarrow 5 \rightarrow 7 ; 1 \rightarrow 2 \rightarrow 4 \rightarrow 6)$, as well $p$-cymene $(3 \rightarrow 8 \rightarrow 11 \rightarrow 14$; $3 \rightarrow 9 \rightarrow 12 \rightarrow 14 ; 3 \rightarrow 10 \rightarrow 13 \rightarrow 14$ ), are not related to each other.

Studies of constants from a physical chemistry perspective for such a complex model only have meaning when kinetic parameters can be modeled separately. Accordingly, to get worthy values of parameters in a specific case of $\alpha$-pinene isomerization, it is useful to manage the isomerization reactions of similar substances. Generally, values of kinetic constants, calculated from such independents experiments, should be combined in the general model, described by Equations (3)-(6). Nevertheless, for reaction modeling, good specification of experimental data allows one to use this model even with the dimensionless parameters collected in Table 8.

Table 8. Statistical parameters.

\begin{tabular}{ccc}
\hline Dimensionless Parameter & Estimated Value & Standard Error $( \pm \mathbf{)}$ \\
\hline $\mathrm{f}_{1}$ & 0.04 & 0.0036 \\
$\mathrm{f}_{2}$ & 0.05 & 0.0011 \\
$\mathrm{f}_{3}$ & 0.08 & 0.0041 \\
$\mathrm{f}_{4}$ & 0.38 & 0.0278 \\
$\mathrm{f}_{5}$ & 0.57 & 0.0294 \\
$\mathrm{f}_{6}$ & 0.19 & 0.0165 \\
$\mathrm{f}_{7}$ & 0.05 & 0.0077 \\
$\mathrm{f}_{8}$ & 0.05 & 0.0082 \\
$\mathrm{f}_{9}$ & 0.04 & 0.0063 \\
\hline
\end{tabular}

The values of the dimensionless parameters in Equations (3)-(6) were obtained for $\alpha$ pinene isomerization over the most efficient activated carbon derived from coffee grounds, and the results are compiled in Table 8 with their standard errors.

The suggested model and mechanism were suitable with the experimental data. The values of the experimental and calculated data were compared; overall, a good fit was achieved. Calculated empirical dimensionless parameters for $\alpha$-pinene isomerization over the activated carbons from coffee grounds achieved in current studies were different from values in our previous studies over clinoptilolite [66]. However, the dependency amongst all parameters was maintained. Moreover, it was confirmed that the $\alpha$-pinene isomerization is a first-order reaction over all activated carbons. However, it was evidenced that the $\alpha$ pinene isomerization rate was different, achieving the highest value over activated carbons derived from coffee grounds.

\section{Conclusions}

In summary, activated carbons from different biomass precursors (orange peels, coffee grounds, and sunflower husks) were prepared successfully by chemical activation using potassium hydroxide. The obtained carbonaceous materials were characterized by a well-developed specific surface area ranging from $1366 \mathrm{~m}^{2} / \mathrm{g}$ to $1566 \mathrm{~m}^{2} / \mathrm{g}$, a total pore 
volume ranging from $0.584 \mathrm{~cm}^{3} / \mathrm{g}$ to $0.694 \mathrm{~cm}^{3} / \mathrm{g}$, and microporous structure ranging from $0.477 \mathrm{~cm}^{3} / \mathrm{g}$ to $0.54 \mathrm{~cm}^{3} / \mathrm{g}$. XRD analysis proved the amorphous structure of the prepared materials. SEM spectroscopy of analyzed samples showed an irregular surface morphology. XPS and XRF spectroscopy showed high purity with trace amounts of inorganic matter content over the surface of obtained carbon materials.

Activated carbons obtained from waste biomass turned out to be active catalysts for the alpha-pinene isomerization process. Among the three tested samples, two were distinguished by particularly high activity in the isomerization process: activated carbons obtained from coffee grounds and orange peels. Such high activity of these two materials most probably resulted from their large specific surface area, as well as from their high content of pores with a diameter of $0.7-1.0,1.1-1.4$, and $1.5-2.5 \mathrm{~nm}$. Pores with the first diameter range seem to be particularly significant for the course of the isomerization process; therefore, the activated carbon obtained from the coffee grounds, which had a larger number of pores in this diameter range compared to the activated carbon obtained from orange peels, was more active in alpha-pinene isomerization. The presence of potassium and chlorine ions in the pores may also be of key importance for the alpha-pinene isomerization process, but this requires further research. Differences in the direction of transformations were observed for the tested catalysts. Time effect studies showed that path A (the pathway to camphene and tricyclene formation) was favored for the catalysts obtained from orange peels and sunflower husk. For the catalyst obtained from coffee grounds, path B, i.e., the formation of monocyclic products (limonene, terpinolene), prevailed. In this case, the size of the product molecule was potentially of great importance for the proper orientation of alpha-pinene transformation. In the case of the catalyst obtained from sunflower husk, almost threefold lower alpha-pinene conversion and significantly higher selectivity of the transformation to $p$-cymene were noticeable.

Generally, for all tested catalysts, the same favorable conditions for carrying out the alpha-pinene isomerization process were determined (temperature $160^{\circ} \mathrm{C}$, amount of catalyst $5 \mathrm{wt} . \%$, and reaction time $3 \mathrm{~h}$ ). However, in the case of the sample of activated carbon obtained from sunflower husk, research should be carried out to increase the activity of this sample, e.g., by impregnating its surface with metals. Taking into account the alphapinene conversion, the results obtained on the $\mathrm{C}_{-} \mathrm{AC}$ catalyst (the most active among those tested) were very similar to the results obtained on the $\mathrm{W}_{2} \mathrm{O}_{3}-\mathrm{Al}_{2} \mathrm{O}_{3}$ catalyst and slightly lower than those on the modified $\mathrm{Al}$ or Ti mesoporous silicates and on the carbon obtained from coffee grounds described in the literature (Table 1). On the other hand, the selectivity of transformation to limonene obtained on this catalyst was very high and close to the best results described in the literature for catalysts such as $\mathrm{HCl}$-modified clinoptilolite and activated carbon from coffee grounds. The selectivity of the transformation to camphene was similar to the results obtained on zeolites, modified silicates, and activated carbon from coffee grounds.

The proposed method of obtaining activated carbons from waste biomass and the way of using these carbons as catalysts for the alpha-pinene isomerization process (the compound obtained from raw materials of natural origin) are examples of an effective way of processing natural resources into materials and compounds with large applications. It should also be emphasized at this point that such raw materials are renewable and have a high availability and relatively low price. This way of obtaining the activated carbons is very simple and requires the use of only two reagents. Thus, this method is cheap, and it does not generate much chemical waste.

Products obtained by alpha-pinene isomerization (camphene and limonene) have numerous applications, both in medicine and in the cosmetics and food industries, as well as in organic synthesis and in the production of polymers. Hence, taking into account the use of cheap activated carbons obtained from waste biomass and obtaining such valuable products of alpha-pinene transformation, this method of alpha-pinene isomerization should be further researched and developed. 
Author Contributions: Conceptualization, A.K., J.S.-N., and A.W.; methodology, A.K., J.S.-N., P.M., and A.W.; validation, J.S.-N., A.W., and R.J.W.; formal analysis, J.S.-N., A.W., K.K., and R.J.W.; investigation, A.K., P.M., and M.K.; data curation, A.K., J.S.-N., and A.W.; writing—original draft preparation, A.K., P.M., K.K., M.K., J.S.-N., R.J.W., and A.W.; writing-review and editing, A.K., P.M., K.K., M.K., J.S.-N., R.J.W., and A.W.; visualization, A.K. and P.M.; supervision, A.W. All authors read and agreed to the published version of the manuscript.

Funding: The APC was funded by Rector of the West Pomeranian University of Technology in Szczecin for PhD students at the Doctoral School, grant number: ZUT/19/2021.

Institutional Review Board Statement: Not applicable.

Informed Consent Statement: Not applicable.

Data Availability Statement: Not applicable.

Conflicts of Interest: The authors declare no conflict of interest.

\section{References}

1. Jędrzak, A.; Rębiś, T.; Klapiszewski, Ł.; Zdarta, J.; Milczarek, G.; Jesionowski, T. Carbon paste electrode based on functional GOx/silica-lignin system to prepare an amperometric glucose biosensor. Sensors Actuators B Chem. 2018, 256, 176-185. [CrossRef]

2. Eriksen, M.H.; Damgaard, C.K.; Christensen, L.H.; McKinnon, D.; Kleveland, K.; Ouacha, M.; Doverfelt, S.; Merta, E.; Arnold, M. Barriers for utilisation of biowaste; TemaNord; Nordic Council of Ministers: Copenhagen, Denmark, 2017 ; ISBN 9789289349062.

3. Martin, M.J.; Artola, A.; Balaguer, M.D.; Rigola, M. Activated carbons developed from surplus sewage sludge for the removal of dyes from dilute aqueous solutions. Chem. Eng. J. 2003, 94, 231-239. [CrossRef]

4. Żółtowska, S.; Bielan, Z.; Zembrzuska, J.; Siwińska-Ciesielczyk, K.; Piasecki, A.; Zielińska-Jurek, A.; Jesionowski, T. Modification of structured bio-carbon derived from spongin-based scaffolds with nickel compounds to produce a functional catalyst for reduction and oxidation reactions: Potential for use in environmental protection. Sci. Total Environ. 2021, 794, 148692. [CrossRef]

5. Kishibayev, K.K.; Serafin, J.; Tokpayev, R.R.; Khavaza, T.N.; Atchabarova, A.A.; Abduakhytova, D.A.; Ibraimov, Z.T.; SreńscekNazzal, J. Physical and chemical properties of activated carbon synthesized from plant wastes and shungite for CO2 capture. J. Environ. Chem. Eng. 2021, 9, 106798. [CrossRef]

6. Aygün, A.; Yenisoy-Karakas, S.; Duman, I. Production of granular activated carbon from fruit stones and nutshells and evaluation of their physical, chemical and adsorption properties. Microporous Mesoporous Mater. 2003, 66, 189-195. [CrossRef]

7. Ouzzine, M.; Serafin, J.; Sreńscek-Nazzal, J. Single step preparation of activated biocarbons derived from pomegranate peels and their CO2 adsorption performance. J. Anal. Appl. Pyrolysis 2021, 160, 105338. [CrossRef]

8. Daouda, M.M.A.; Akowanou, A.V.O.; Mahunon, S.E.R.; Adjinda, C.K.; Aina, M.P.; Drogui, P. Optimal removal of diclofenac and amoxicillin by activated carbon prepared from coconut shell through response surface methodology. S. Afr. J. Chem. Eng. 2021, 38, 78-89. [CrossRef]

9. Namasivayam, C.; Kadirvelu, K. Activated carbons prepared from coir pith by physical and chemical activation methods. Bioresour. Technol. 1997, 62, 123-127. [CrossRef]

10. Serafin, J.; Ouzzine, M.; Cruz, O.F.; Sreńscek-Nazzal, J.; Campello Gómez, I.; Azar, F.-Z.; Rey Mafull, C.A.; Hotza, D.; Rambo, C.R. Conversion of fruit waste-derived biomass to highly microporous activated carbon for enhanced CO2 capture. Waste Manag. 2021, 136, 273-282. [CrossRef]

11. Daud, W.M.A.W.; Ali, W.S.W.; Sulaiman, M.Z. The effects of carbonization temperature on pore development in palm-shell-based activated carbon. Carbon N. Y. 2000, 38, 1925-1932. [CrossRef]

12. Herawan, S.G.; Hadi, M.S.; Ayob, M.R.; Putra, A. Characterization of Activated Carbons from Oil-Palm Shell by CO 2 Activation with No Holding Carbonization Temperature. Sci. World J. 2013, 2013, 624865. [CrossRef]

13. Puig-Gamero, M.; Esteban-Arranz, A.; Sanchez-Silva, L.; Sánchez, P. Obtaining activated biochar from olive stone using a bench scale high-pressure thermobalance. J. Environ. Chem. Eng. 2021, 9, 105374. [CrossRef]

14. Prahas, D.; Kartika, Y.; Indraswati, N.; Ismadji, S. Activated carbon from jackfruit peel waste by H3PO4 chemical activation: Pore structure and surface chemistry characterization. Chem. Eng. J. 2008, 140, 32-42. [CrossRef]

15. Teo, E.Y.L.; Muniandy, L.; Ng, E.-P.; Adam, F.; Mohamed, A.R.; Jose, R.; Chong, K.F. High surface area activated carbon from rice husk as a high performance supercapacitor electrode. Electrochim. Acta 2016, 192, 110-119. [CrossRef]

16. Van Thuan, T.; Quynh, B.T.P.; Nguyen, T.D.; Ho, V.T.T.; Bach, L.G. Response surface methodology approach for optimization of $\mathrm{Cu} 2+, \mathrm{Ni2}+$ and $\mathrm{Pb} 2+$ adsorption using $\mathrm{KOH}$-activated carbon from banana peel. Surf. Interfaces 2017, 6, 209-217. [CrossRef]

17. Depci, T.; Kul, A.R.; Önal, Y. Competitive adsorption of lead and zinc from aqueous solution on activated carbon prepared from Van apple pulp: Study in single- and multi-solute systems. Chem. Eng. J. 2012, 200-202, 224-236. [CrossRef]

18. Tian, X.; Ma, H.; Li, Z.; Yan, S.; Ma, L.; Yu, F.; Wang, G.; Guo, X.; Ma, Y.; Wong, C. Flute type micropores activated carbon from cotton stalk for high performance supercapacitors. J. Power Sources 2017, 359, 88-96. [CrossRef] 
19. Saeidian, H.; Khajeh, S.V.; Mirjafary, Z.; Eftekhari-Sis, B. Immobilized copper nanoparticles on nitrogen-rich porous activated carbon from egg white biomass: A robust hydrophilic-hydrophobic balance catalyst for click reaction. RSC Adv. 2018, 8, 3880138807. [CrossRef]

20. Szatkowski, T.; Kopczyński, K.; Motylenko, M.; Borrmann, H.; Mania, B.; Graś, M.; Lota, G.; Bazhenov, V.V.; Rafaja, D.; Roth, F.; et al. Extreme biomimetics: A carbonized 3D spongin scaffold as a novel support for nanostructured manganese oxide(IV) and its electrochemical applications. Nano Res. 2018, 11, 4199-4214. [CrossRef]

21. Teixeira, F.; dos Santos, B.A.; Nunes, G.; Soares, J.M.; do Amaral, L.A.; de Souza, G.H.O.; de Resende, J.T.V.; Menegassi, B.; Rafacho, B.P.M.; Schwarz, K.; et al. Addition of Orange Peel in Orange Jam: Evaluation of Sensory, Physicochemical, and Nutritional Characteristics. Molecules 2020, 25, 1670. [CrossRef] [PubMed]

22. Martín, M.A.; Siles, J.A.; Chica, A.F.; Martín, A. Biomethanization of orange peel waste. Bioresour. Technol. 2010, 101, 8993-8999. [CrossRef]

23. Santos, C.M.; Dweck, J.; Viotto, R.S.; Rosa, A.H.; de Morais, L.C. Application of orange peel waste in the production of solid biofuels and biosorbents. Bioresour. Technol. 2015, 196, 469-479. [CrossRef] [PubMed]

24. Rivas, B.; Torrado, A.; Torre, P.; Converti, A.; Domínguez, J.M. Submerged Citric Acid Fermentation on Orange Peel Autohydrolysate. J. Agric. Food Chem. 2008, 56, 2380-2387. [CrossRef]

25. Kosseva, M.R. Sources, characteristics and treatment of plant-based food waste. In Food Industry Wastes; Elsevier: Amsterdam, The Netherlands, 2020; pp. 37-66.

26. De Medina-Salas, L.; Giraldi-Díaz, M.R.; Castillo-González, E.; Morales-Mendoza, L.E. Valorization of orange peel waste using precomposting and vermicomposting processes. Sustainability 2020, 12, 7626. [CrossRef]

27. Chen, B.; Chen, Z. Sorption of naphthalene and 1-naphthol by biochars of orange peels with different pyrolytic temperatures. Chemosphere 2009, 76, 127-133. [CrossRef] [PubMed]

28. Fernandez, M.E.; Nunell, G.V.; Bonelli, P.R.; Cukierman, A.L. Activated carbon developed from orange peels: Batch and dynamic competitive adsorption of basic dyes. Ind. Crops Prod. 2014, 62, 437-445. [CrossRef]

29. Arie, A.A.; Kristianto, H.; Suharto, I.; Halim, M.; Lee, J.K. Preparation of Orange Peel Based Activated Carbons as Cathodes in Lithium Ion Capacitors. Adv. Mater. Res. 2014, 896, 95-99. [CrossRef]

30. Wei, Q.; Chen, Z.; Cheng, Y.; Wang, X.; Yang, X.; Wang, Z. Preparation and electrochemical performance of orange peel based-activated carbons activated by different activators. Colloids Surf. A Physicochem. Eng. Asp. 2019, 574, 221-227. [CrossRef]

31. Giraldo, L.; Moreno-Pirajan, J.C. Activated Carbon Prepared From Orange Peels Coated With Titanium Oxide Nanoparticles: Characterization and Applications in the Decomposition of NOx. Orient. J. Chem. 2014, 30, 451-461. [CrossRef]

32. Pan, H.; Sun, J.; Liu, J.; Zhang, Y.; Zhou, S. Preparation of sulfonated carbon derived from orange peel and its application in esterification. Chem. Phys. Lett. 2021, 770, 138395. [CrossRef]

33. Arcibar-Orozco, J.A.; Rangel-Mendez, J.R.; Bandosz, T.J. Reactive adsorption of SO2 on activated carbons with deposited iron nanoparticles. J. Hazard. Mater. 2013, 246-247, 300-309. [CrossRef] [PubMed]

34. Veerakumar, P.; Veeramani, V.; Chen, S.M.; Madhu, R.; Liu, S. Bin Palladium Nanoparticle Incorporated Porous Activated Carbon: Electrochemical Detection of Toxic Metal Ions. ACS Appl. Mater. Interfaces 2016, 8, 1319-1326. [CrossRef]

35. Butt, M.S.; Sultan, M.T. Coffee and its consumption: Benefits and risks. Crit. Rev. Food Sci. Nutr. 2011, 51, 363-373. [CrossRef]

36. Roussos, S.; de los Angeles Aquiáhuatl, M.; del Refugio Trejo-Hernández, M.; Gaime Perraud, I.; Favela, E.; Ramakrishna, M.; Raimbault, M.; Viniegra-González, G. Biotechnological management of coffee pulp - isolation, screening, characterization, selection of caffeine-degrading fungi and natural microflora present in coffee pulp and husk. Appl. Microbiol. Biotechnol. 1995, 42, 756-762. [CrossRef]

37. Wen, X.; Liu, H.; Zhang, L.; Zhang, J.; Fu, C.; Shi, X.; Chen, X.; Mijowska, E.; Chen, M.-J.; Wang, D.-Y. Large-scale converting waste coffee grounds into functional carbon materials as high-efficient adsorbent for organic dyes. Bioresour. Technol. 2019, 272, 92-98. [CrossRef] [PubMed]

38. Figueroa Campos, G.A.; Perez, J.P.H.; Block, I.; Sagu, S.T.; Saravia Celis, P.; Taubert, A.; Rawel, H.M. Preparation of Activated Carbons from Spent Coffee Grounds and Coffee Parchment and Assessment of Their Adsorbent Efficiency. Processes 2021, 9, 1396. [CrossRef]

39. Wang, H.; Li, X.; Cui, Z.; Fu, Z.; Yang, L.; Liu, G.; Li, M. Coffee grounds derived N enriched microporous activated carbons: Efficient adsorbent for post-combustion CO2 capture and conversion. J. Colloid Interface Sci. 2020, 578, 491-499. [CrossRef]

40. Goncalves, M.; Castro, C.S.; Oliveira, L.C.A.; Carvalho, W.A. Green acid catalyst obtained from industrial wastes for glycerol etherification. Fuel Process. Technol. 2015, 138, 695-703. [CrossRef]

41. Lykoudi, A.; Frontistis, Z.; Vakros, J.; Manariotis, I.D.; Mantzavinos, D. Degradation of sulfamethoxazole with persulfate using spent coffee grounds biochar as activator. J. Environ. Manag. 2020, 271, 111022. [CrossRef]

42. Agapay, R.C.; Liu, H.-C.; Ju, Y.-H.; Go, A.W.; Angkawijaya, A.E.; Nguyen, P.L.T.; Truong, C.T.; Quijote, K.L. Synthesis and Initial Evaluation of Solid Acid Catalyst Derived from Spent Coffee Grounds for the Esterification of Oleic Acid and Methanol. Waste Biomass Valorization 2021, 12, 4387-4397. [CrossRef]

43. Luna-Lama, F.; Rodríguez-Padrón, D.; Puente-Santiago, A.R.; Muñoz-Batista, M.J.; Caballero, A.; Balu, A.M.; Romero, A.A.; Luque, R. Non-porous carbonaceous materials derived from coffee waste grounds as highly sustainable anodes for lithium-ion batteries. J. Clean. Prod. 2019, 207, 411-417. [CrossRef] 
44. Zhang, Z.; Yang, S.; Li, H.; Zan, Y.; Li, X.; Zhu, Y.; Dou, M.; Wang, F. Sustainable Carbonaceous Materials Derived from Biomass as Metal-Free Electrocatalysts. Adv. Mater. 2019, 31, 1805718. [CrossRef] [PubMed]

45. Liu, X.; Zhang, S.; Wen, X.; Chen, X.; Wen, Y.; Shi, X.; Mijowska, E. High yield conversion of biowaste coffee grounds into hierarchical porous carbon for superior capacitive energy storage. Sci. Rep. 2020, 10, 3518. [CrossRef] [PubMed]

46. Wroniak, M.; Agnieszka, R. Innowacyjne Rozwiązania w Technologii Żywności i żywieniu Człowieka; Oddział Małopolski Polskiego Towarzystwa Technologów Żywności: Kraków, Poland, 2016.

47. Geneau-Sbartaï, C.; Leyris, J.; Silvestre, F.; Rigal, L. Sunflower Cake as a Natural Composite: Composition and Plastic Properties. J. Agric. Food Chem. 2008, 56, 11198-11208. [CrossRef]

48. Thinakaran, N.; Baskaralingam, P.; Pulikesi, M.; Panneerselvam, P.; Sivanesan, S. Removal of Acid Violet 17 from aqueous solutions by adsorption onto activated carbon prepared from sunflower seed hull. J. Hazard. Mater. 2008, 151, 316-322. [CrossRef]

49. Foo, K.Y.; Hameed, B.H. Preparation and characterization of activated carbon from sunflower seed oil residue via microwave assisted K 2CO 3 activation. Bioresour. Technol. 2011, 102, 9794-9799. [CrossRef]

50. Saleh, M.E.; El-Refaey, A.A.; Mahmoud, A.H. Effectiveness of sunflower seed husk biochar for removing copper ions from wastewater: A comparative study. Soil Water Res. 2016, 11, 53-63. [CrossRef]

51. Hameed, B.H.; Rahman, A.A. Removal of phenol from aqueous solutions by adsorption onto activated carbon prepared from biomass material. J. Hazard. Mater. 2008, 160, 576-581. [CrossRef] [PubMed]

52. Trytek, M.; Paduch, R.; Fiedurek, J.; Kandefer-Szerszeń, M. Monoterpeny-Stare związki, nowe zastosowania i biotechnologiczne metody ich otrzymywania. Biotechnologia 2007, 76, 135-155.

53. Van Groenestijn, J.W.; Liu, J.X. Removal of alpha-pinene from gases using biofilters containing fungi. Atmos. Environ. 2002, 36, 5501-5508. [CrossRef]

54. Sinhmar, P.S.; Gogate, P.R. Improved Activation of Titanium Dioxide Catalyst for Isomerization of Alpha Pinene and Understanding into Effect of Isomerization Parameters. Arab. J. Sci. Eng. 2021. [CrossRef]

55. Michalkiewicz, B. The kinetics of homogeneous catalytic methane oxidation. Appl. Catal. A Gen. 2006, 307, 270-274. [CrossRef]

56. Sarkic, A.; Stappen, I. Essential oils and their single compounds in cosmetics-a critical review. Cosmetics 2018, 5, 11. [CrossRef]

57. Ponomarev, D.; Mettee, H. Camphor and its Industrial Synthesis. Chem. Educ. J. 2016, 18, 1-4.

58. Kapp, T.; Kammann, U.; Vobach, M.; Vetter, W. Synthesis of low and high chlorinated toxaphene and comparison of their toxicity by zebrafish (Danio rerio) embryo test. Environ. Toxicol. Chem. 2006, 25, 2884-2889. [CrossRef]

59. Sánchez-Velandia, J.E.; Pájaro, E.; Villa, A.L.; Martínez-O, F. Selective synthesis of camphene from isomerization of $\alpha-$ and $\beta$-pinene over heterogeneous catalysts. Microporous Mesoporous Mater. 2021, 324, 111273. [CrossRef]

60. Retajczyk, M.; Wróblewska, A.; Szymańska, A.; Michalkiewicz, B. Isomerization of limonene over natural zeolite-clinoptilolite. Clay Miner. 2019, 54, 121-129. [CrossRef]

61. Młodzik, J.; Wróblewska, A.; Makuch, E.; Wróbel, R.J.; Michalkiewicz, B. Fe/EuroPh catalysts for limonene oxidation to 1,2-epoxylimonene, its diol, carveol, carvone and perillyl alcohol. Catal. Today 2016, 268, 111-120. [CrossRef]

62. Wróblewska, A. The epoxidation of limonene over the ts-1 and ti-sba-15 catalysts. Molecules 2014, 19, 19907-19922. [CrossRef]

63. Ravichandran, C.; Badgujar, P.C.; Gundev, P.; Upadhyay, A. Review of toxicological assessment of d-limonene, a food and cosmetics additive. Food Chem. Toxicol. 2018, 120, 668-680. [CrossRef]

64. Kumar, V.; Agarwal, A.K. a Review on Catalytic Terpene Transformation Over Heterogeneous Catalyst. Chem. Int. J. Curr. Res. Chem. Pharma. Sci. 2014, 1, 78-88.

65. Ünveren, E.; Günüz, G.; Cakicioğlu-Özkan, F. Isomerization of alpha-pinene over acid treated natural zeolite. Chem. Eng. Commun. 2005, 192, 386-404. [CrossRef]

66. Miądlicki, P.; Wróblewska, A.; Kiełbasa, K.; Koren, Z.C.; Michalkiewicz, B. Sulfuric acid modified clinoptilolite as a solid green catalyst for solvent-free $\alpha$-pinene isomerization process. Microporous Mesoporous Mater. 2021, 324, 111266. [CrossRef]

67. Sidorenko, A.Y.; Aho, A.; Ganbaatar, J.; Batsuren, D.; Utenkova, D.B.; Sen'kov, G.M.; Wärnå, J.; Murzin, D.Y.; Agabekov, V.E. Catalytic isomerization of A-pinene and 3-carene in the presence of modified layered aluminosilicates. Mol. Catal. 2017, 443, 193-202. [CrossRef]

68. Zielinska, B.; Michalkiewicz, B.; Chen, X.; Mijowska, E.; Kalenczuk, R.J. Pd supported ordered mesoporous hollow carbon spheres (OMHCS) for hydrogen storage. Chem. Phys. Lett. 2016, 647, 14-19. [CrossRef]

69. Akgül, M.; özyaĝci, B.; Karabakan, A. Evaluation of Fe- and Cr-containing clinoptilolite catalysts for the production of camphene from $\alpha$-pinene. J. Ind. Eng. Chem. 2013, 19, 240-249. [CrossRef]

70. Zou, J.-J.; Chang, N.; Zhang, X.; Wang, L. Isomerization and Dimerization of Pinene using Al-Incorporated MCM-41 Mesoporous Materials. ChemCatChem 2012, 4, 1289-1297. [CrossRef]

71. Wróblewska, A.; Miądlicki, P.; Tołpa, J.; Sreńscek-Nazzal, J.; Koren, Z.C.; Michalkiewicz, B. Influence of the titanium content in the Ti-MCM-41 catalyst on the course of the $\alpha$-pinene isomerization process. Catalysts 2019, 9, 396. [CrossRef]

72. Wróblewska, A.; Miądlicki, P.; Sreńscek-Nazzal, J.; Sadłowski, M.; Koren, Z.C.; Michalkiewicz, B. Alpha-pinene isomerization over Ti-SBA-15 catalysts obtained by the direct method: The influence of titanium content, temperature, catalyst amount and reaction time. Microporous Mesoporous Mater. 2018, 258, 72-82. [CrossRef]

73. Lubkowski, K.; Arabczyk, W.; Grzmil, B.; Michalkiewicz, B.; Pattek-Janczyk, A. Passivation and oxidation of an ammonia iron catalyst. Appl. Catal. A Gen. 2007, 329, 137-147. [CrossRef] 
74. Launay, F.; Jarry, B.; Bonardet, J.L. Catalytic activity of mesoporous Ga-SBA-15 materials in $\alpha$-pinene isomerisation: Similarities and differences with Al-SBA-15 analogues. Appl. Catal. A Gen. 2009, 368, 132-138. [CrossRef]

75. Akpolat, O.; Gündüz, G.; Ozkan, F.; Beşün, N. Isomerization of $\alpha$-pinene over calcined natural zeolites. Appl. Catal. A Gen. 2004, 265, 11-22. [CrossRef]

76. Grams, J.; Potrzebowska, N.; Goscianska, J.; Michalkiewicz, B.; Ruppert, A.M. Mesoporous silicas as supports for Ni catalyst used in cellulose conversion to hydrogen rich gas. Int. J. Hydrogen Energy 2016, 41, 8656-8667. [CrossRef]

77. Sánchez-Velandia, J.E.; Gelves, J.F.; Márquez, M.A.; Dorkis, L.; Villa, A.L. Catalytic Isomerization of $\alpha$-Pinene Epoxide Over a Natural Zeolite. Catal. Letters 2020, 150, 3132-3148. [CrossRef]

78. Tzompantzi, F.; Valverde, M.; Pérez, A.; Rico, J.L.; Mantilla, A.; Gómez, R. Synthesis of camphene by $\alpha$-pinene isomerization using $\mathrm{W}_{2} \mathrm{O}_{3}-\mathrm{Al}_{2} \mathrm{O}_{3}$ catalysts. Top. Catal. 2010, 53, 1176-1178. [CrossRef]

79. da Silva Rocha, K.A.; Robles-Dutenhefner, P.A.; Kozhevnikov, I.V.; Gusevskaya, E.V. Phosphotungstic heteropoly acid as efficient heterogeneous catalyst for solvent-free isomerization of $\alpha$-pinene and longifolene. Appl. Catal. A Gen. 2009, 352, 188-192. [CrossRef]

80. Liu, Y.; Li, L.; Xie, C.X. Acidic functionalized ionic liquids as catalyst for the isomerization of $\alpha$-pinene to camphene. Res. Chem. Intermed. 2016, 42, 559-569. [CrossRef]

81. Wang, J.; Hua, W.; Yue, Y.; Gao, Z. MSU-S mesoporous materials: An efficient catalyst for isomerization of $\alpha$-pinene. Bioresour. Technol. 2010, 101, 7224-7230. [CrossRef]

82. Rabee, A.I.M.; Durndell, L.J.; Fouad, N.E.; Frattini, L.; Isaacs, M.A.; Lee, A.F.; Mekhemer, G.A.H.; do Santos, V.C.; Wilson, K.; Zaki, M.I. Citrate-mediated sol-gel synthesis of Al-substituted sulfated zirconia catalysts for $\alpha$-pinene isomerization. Mol. Catal. 2018, 458, 206-212. [CrossRef]

83. Zou, Z.; Tang, Y.; Jiang, C.; Zhang, J. Efficient adsorption of $\mathrm{Cr}(\mathrm{VI})$ on sunflower seed hull derived porous carbon. J. Environ. Chem. Eng. 2015, 3, 898-905. [CrossRef]

84. Sing, K.S.W.; Everett, D.H.; Haul, R.A.W.; Moscou, L.; Pierotti, R.A.; Rouquerol, J.; Siemieniewska, T. Reporting Physisorption Data for Gas/Solid Systems with Special Reference to the Determination of Surface Area and Porosity. Pure Appl. Chem. 1985, 57, 603-619. [CrossRef]

85. Thommes, M.; Kaneko, K.; Neimark, A.V.; Olivier, J.P.; Rodriguez-Reinoso, F.; Rouquerol, J.; Sing, K.S.W. Physisorption of gases, with special reference to the evaluation of surface area and pore size distribution (IUPAC Technical Report). Pure Appl. Chem. 2015, 87, 1051-1069. [CrossRef]

86. Zhang, X.; Shi, X.; Zhao, Q.; Li, Y.; Wang, J.; Yang, Y.; Bi, F.; Xu, J.; Liu, N. Defects controlled by acid-modulators and water molecules enabled UiO-67 for exceptional toluene uptakes: An experimental and theoretical study. Chem. Eng. J. 2022, 427, 131573. [CrossRef]

87. Yang, Y.; Zhang, D.; Ji, W.; Bi, F.; Song, L.; Zhang, X. Uniform platinum nanoparticles loaded on Universitetet i Oslo-66 (UiO-66): Active and stable catalysts for gas toluene combustion. J. Colloid Interface Sci. 2022, 606, 1811-1822. [CrossRef]

88. Serafin, J.; Kiełbasa, K.; Michalkiewicz, B. The new tailored nanoporous carbons from the common polypody (Polypodium vulgare): The role of textural properties for enhanced CO2 adsorption. Chem. Eng. J. 2022, 429, 131751. [CrossRef]

89. Muniandy, L.; Adam, F.; Mohamed, A.R.; Ng, E.P. The synthesis and characterization of high purity mixed microporous/mesoporous activated carbon from rice husk using chemical activation with $\mathrm{NaOH}$ and KOH. Microporous Mesoporous Mater. 2014, 197, 316-323. [CrossRef]

90. Yang, T.; Lua, A.C. Textural and chemical properties of zinc chloride activated carbons prepared from pistachio-nut shells. Mater. Chem. Phys. 2006, 100, 438-444. [CrossRef]

91. Jiang, Y.; Li, J.; Jiang, Z.; Shi, M.; Sheng, R.; Liu, Z.; Zhang, S.; Cao, Y.; Wei, T.; Fan, Z. Large-surface-area activated carbon with high density by electrostatic densification for supercapacitor electrodes. Carbon N. Y. 2021, 175, 281-288. [CrossRef]

92. Martínez-Casillas, D.C.; Mascorro-Gutiérrez, I.; Arreola-Ramos, C.E.; Villafán-Vidales, H.I.; Arancibia-Bulnes, C.A.; RamosSánchez, V.H.; Cuentas-Gallegos, A.K. A sustainable approach to produce activated carbons from pecan nutshell waste for environmentally friendly supercapacitors. Carbon N. Y. 2019, 148, 403-412. [CrossRef]

93. Pagalan, E.; Sebron, M.; Gomez, S.; Salva, S.J.; Ampusta, R.; Macarayo, A.J.; Joyno, C.; Ido, A.; Arazo, R. Activated carbon from spent coffee grounds as an adsorbent for treatment of water contaminated by aniline yellow dye. Ind. Crops Prod. 2020, 145, 111953. [CrossRef]

94. Gęsikiewicz-Puchalska, A.; Zgrzebnicki, M.; Michalkiewicz, B.; Narkiewicz, U.; Morawski, A.W.; Wrobel, R.J. Improvement of CO2 uptake of activated carbons by treatment with mineral acids. Chem. Eng. J. 2017, 309, 159-171. [CrossRef]

95. Wijayati, N.; Pranowo, H.D.; Jumina, T.; Chuah, G.K. Characterization of ZHY and TCA/ZHY Catalysts for Hydration of $\alpha$-Pinene. Int. J. Chem. Eng. Appl. 2013, 4, 178-182. [CrossRef]

96. Zielińska, B.; Wróblewska, A.; Maślana, K.; Miądlicki, P.; Kiełbasa, K.; Rozmysłowska-Wojciechowska, A.; Petrus, M.; Woźniak, J.; Jastrzębska, A.M.; Michalkiewicz, B.; et al. High catalytic performance of 2D Ti3C2Tx MXene in $\alpha$-pinene isomerization to camphene. Appl. Catal. A Gen. 2020, 604, 117765. [CrossRef]

97. Allahverdiev, A.I.; Irandoust, S.; Murzin, D.Y. Isomerization of $\alpha$-pinene over clinoptilolite. J. Catal. 1999, 185, 352-362. [CrossRef] 